\title{
Article \\ Evaluating Outdoor Thermal Comfort Using a Mixed-Method to Improve the Environmental Quality of a University Campus
}

\author{
Nasim Eslamirad ${ }^{1, *}$, Abel Sepúlveda ${ }^{2}\left(\mathbb{D}\right.$, Francesco De Luca ${ }^{2}$ and Kimmo Sakari Lylykangas ${ }^{2}$ \\ 1 FinEst Centre for Smart Cities, Tallinn University of Technology, 19086 Tallinn, Estonia \\ 2 Department of Civil Engineering and Architecture, Academy of Architecture and Urban Studies, \\ Tallinn University of Technology, 19086 Tallinn, Estonia; absepu@taltech.ee (A.S.); \\ francesco.deluca@taltech.ee (F.D.L.); kimmo.lylykangas@taltech.ee (K.S.L.) \\ * Correspondence: nasim.eslamirad@taltech.ee; Tel.: +372-58-188-087
}

Citation: Eslamirad, N.; Sepúlveda, A.; De Luca, F.; Sakari Lylykangas, K. Evaluating Outdoor Thermal Comfort Using a Mixed-Method to Improve the Environmental Quality of a University Campus. Energies 2022, 15, 1577. https://doi.org/ 10.3390/en15041577

Academic Editor: Vincenzo Costanzo

Received: 16 January 2022

Accepted: 16 February 2022

Published: 21 February 2022

Publisher's Note: MDPI stays neutral with regard to jurisdictional claims in published maps and institutional affiliations.

Copyright: () 2022 by the authors. Licensee MDPI, Basel, Switzerland. This article is an open access article distributed under the terms and conditions of the Creative Commons Attribution (CC BY) license (https:// creativecommons.org/licenses/by/ $4.0 /)$.

\begin{abstract}
Thermal comfort in cities is increasingly becoming a concern and comfortable places can be highly valuable for a variety of activities. Our investigation aims to explore how to improve the quality of cities by considering the relationship between microclimatic conditions, thermal sensation, and human preferences. The case study conducted in the open areas of Tallinn University of Technology (TalTech) campus, which is quite populated by visitors, staff, and students. We used a mixed-methods approach to assess outdoor thermal comfort, based on qualitative and quantitative findings of the relationships between the measured weather conditions and the results of thermal comfort assessment through the PET index and subjectively perceived thermal sensation. In the qualitative part, data was collected through semi-structured interviews. The main conclusions from the interviews were used to design a survey and the samples. Based on the results, it was possible to identify places that offer different levels of thermal comfort. Thus, the study helps to improve thermal comfort at the campus, which is one of the goals of the Green Transition project to make the campus fully sustainable. Moreover, the methodology is applicable in different urban areas to improve urban health and sustainability and create resilient urban environments.
\end{abstract}

Keywords: survey; semi structured interview; outdoor thermal comfort optimization; urban simulation

\section{Introduction}

In the context of urban planning, it is interesting how thermally comfortable urban environments influence people's behavior, use of outdoor spaces, and the quality of life in cities [1]. Sustainable cities are designed with their environmental impact in mind [2]. Moreover, the number of users of outdoor spaces would determine the vibrancy of the place, the local socio-economy, and sustainability of the city [3]. In addition, outdoor microclimate or related outdoor thermal comfort is an important factor influencing the quality of urban spaces [3]. As weather and location invite people to be active in urban spaces where many outdoor activities take place, activity levels in cities are influenced by a range of urban conditions [4]. However, in contrast, uncomfortable and low-quality outdoor spaces cause people to rush home [5]. According to Gehl, since voluntary activities are more likely to take place when outdoor space is of good quality, the number of social activities that depend on the presence of others in public space also tends to increase significantly [4]. In addition, pedestrians are directly exposed to the immediate environment in the form of variations in sun/shade and shade, wind speed [1], and other weather features during recreation and leisure in the outdoor spaces $[1,6]$. Therefore, the quality of outdoor spaces affects the quality of life of residents [3], and microclimatic conditions have significant impact on urban development [7]. Accordingly, one of the main objectives in the study of thermal comfort is to find out the relationship between the thermal environment and the thermal perception of the inhabitants [8]. 
Urban planners are increasingly concerned with the impact of climate on urban planning [9]. They are constantly striving to maintain and improve the quality of life of city dwellers by creating comfortable and pleasant environment [10]. Indeed, outdoor quality of life is one of the essential parameter to assess the quality of the urban microclimate [11] and can be improved through various design concepts and solutions to make public spaces more livable and pleasant [12]. Similarly, studies on thermal comfort at an urban scale create a close link between urban and landscape planners to pay more attention to pedestrians (biometeorology) and climate (climatology) [13]. In addition, outdoor thermal comfort has received great attention since the start of the new millennium [14]. Nevertheless, due to the great complexity of the outdoor environment in terms of temporal and spatial variability and the variety of activities that people engage in, there have been very few attempts to understand outdoor comfort conditions [12]. Therefore, there is a lack of studies trying to find out the relationship between people's thermal perceptions and the ranges of thermal comfort in urban areas and the cause-effect elements.

Thanks to advances in urban climatology and biometeorological techniques, some detailed microclimatic analyses and assessments of thermal comfort have been conducted in recent decades [1]. A criterion for qualitative assessment would also be helpful in creating comfortable urban spaces [6]. In addition, there is a lack of understanding of urban features that provide a comfortable urban space to urban dwellers, considering both qualitative and quantitative features. To further explore these subjectivities, this paper aims to explore (i) the objective and subjective elements in defining outdoor thermal comfort, (ii) the use of both qualitative and quantitative research methods in assessing outdoor thermal comfort and the level of comfortability in each area, and (iii) how and to what extent all personal factors, weather conditions, and urban features influence the sense of outdoor thermal comfort.

\subsection{Background of Outdoor Thermal Comfort Evaluation}

Since 1920, studies on the human thermal environment and various thermal indices based on air temperature and relative humidity have been developed. A classical concept to describe thermal perception was developed by Fanger who described "thermal comfort" as "man's satisfaction with his thermal environment" [5,15]. In 1960, Fanger started to study thermal comfort [16] and defined this concept for indoor spaces and also developed a physiological index Predicted Mean Vote (PMV) to describe "thermal comfort" quantitatively [5], while his first results were published in 1967 [16]. Fanger's equation was the basis for ISO 7730 [17] and ASHRAE 55 [18]. The main thermal comfort standard [17] was based on PMV and PPD that considers the criteria like ISO 8996 (metabolic rate) and ISO 9920 (clothing) and describes the PMV and PPD indices and specifies acceptable conditions for thermal comfort [19].

Numerous thermal comfort biometeorological indices such as standard effective temperature (SET), PMV, physiological equivalent temperature (PET), universal thermal climate index (UTCI), perceived temperature (PT), and outdoor standard effective temperature (OUT_SET) have been developed to describe human thermal comfort by establishing a link between local microclimatic conditions and human thermal sensation [1,5]. PET is based on the Munich energy balance model for individuals (MEMI) as an index with temperature dimension expressed in degrees Celsius $\left({ }^{\circ} \mathrm{C}\right)$, which makes its interpretation understandable even for people without much knowledge of meteorology [1]. Table 1 shows PET in the different thermal perception by human. PET is defined using the concept of equivalent temperature: it is the indoor air temperature of an isothermal environment that produces the same core and skin temperature as the actual complex outdoor conditions. In this typical room the ambient conditions are homogeneous, the air is calm $(<0.1 \mathrm{~m} / \mathrm{s})$, and the vapor pressure is $1200 \mathrm{~Pa}\left(50 \%\right.$ relative humidity at $\left.20^{\circ} \mathrm{C}\right)$. Thus, PET allows a layman to compare the integrated effects of complex outdoor thermal conditions with his own experience indoors [13]. Another study, Lin used PET as the primary thermal index [20]. Other studies used PET to determine neutral temperature in different climatic regions [21-23]. 
PMV and SET are based on the physically based heat balance and heat transfer model [8]. OUT_SET and PET are both based on steady-state energy balance models of the human body. Their application is limited to situations where people spend long periods of time outdoors [24].

Table 1. Ranges of the thermal index of PET for different grades of thermal perception by human [13].

\begin{tabular}{ccc}
\hline PET $\left({ }^{\circ} \mathbf{C}\right)$ & $\begin{array}{c}\text { Thermal Perception } \\
\text { (Internal Heat Production: 80 W, Heat } \\
\text { Transfer Resistance of the Clothing: 0.9) }\end{array}$ & Grade of Physiological Stress \\
\hline 4 & Very Cold & Extreme cold stress \\
Cold & Strong cold stress \\
8 & Cool & Moderate cold stress \\
13 & Slightly cool & Slight cold stress \\
18 & Comfortable & No thermal stress \\
23 & Slightly warm & Slightly heat stress \\
35 & Warm & Moderate heat stress \\
41 & Hot & Strong heat stress \\
\hline
\end{tabular}

The UTCI metric was developed by 45 scientists from 23 countries to standardize applications in the most important areas of human biometeorology [14]. The UTCI metric is expressed as the equivalent ambient temperature of a reference environment that produces the same physiological response in a reference subject as the actual environment [25]. The UTCI has been called for by various disciplines as a physiological response-based assessment index that is valid for a wide range of outdoor climatic conditions, including weather extremes.

Due to the different indices of thermal comfort, assessment methods, and procedures used in the different studies, the results may not be comparable. Table 1 shows PET in the different thermal perception by human. Another study, Lin [20] used PET as the primary thermal index, and Ng et al. [21], Kántor et al. [22], and Kruger et al. [23] used PET to determine neutral temperature in the climatic regions they studied. In addition, the UTCI was developed by 45 scientists from 23 countries [14] to standardize applications in the most important areas of human biometeorology.

\subsection{Literature Review}

There has been significant effort to investigate the influence factors of outdoor thermal comfort and assessment methods. Unlike indoor environments, urban microclimates, are dynamic and the changing sunlight, wind and shading from trees make the environment volatile [9]. In addition to the climatic aspects of thermal comfort, a number of physical and social factors come into play that influence people's perception of urban space when they are outdoors [1]. In 1971, Gehl studied the influence of microclimate on outdoor activities and showed that sunny or shady local conditions significantly influence people's desire to either stay or leave [4].

Nikolopoulou et al. were pioneers addressing human behavior, research frameworks and analytical procedures [1]. They asked people, within the context of recreational areas in Cambridge, UK, about their subjective thermal sensation, which were given on a five-point scale from too cold to too hot. They also considered environmental characteristics (air temperature, sunlight, etc.) and individual characteristics (age, gender, clothing, etc.) [1] Nikolopoulou et al. showed that the thermal environment is indeed of prime importance 
for users of urban spaces, but psychological adaptation, i.e., available choices, environmental stimulation, thermal history, memory effect, and expectations are also of great importance [26].

The environmental stimulus (i.e., local microclimatic conditions) is the most important factor influencing thermal sensation and human assessments of comfort [1]. These assessments are dynamic in the sense that adaptation to a thermal environmental condition is progressive and that thermal sensation is primarily influenced by experience, and subjective, which implies that the assessment of a thermal comfort condition does not always correspond to objective climatic or biometeorological conditions [1]. Kenz et al. reported significant influences of weather parameters and personal factors on participants perceived and subjective evaluations of outdoor urban areas [27].

Lenzholzer et al. used qualitative methods to design thermally comfortable urban space, linking thermal and spatial information from to people's perceptions [5]. Zacharias et al. investigated seven corporate plazas and public spaces in the city center of a North American city (Montreal) to determine the relationship between the local microclimate and the level of use, measured as the degree of presence of people and activities (sitting, standing, and smoking) [1]. The other study integrates theoretical findings on outdoor thermal comfort, weather perception, and emotional experience related to travel behavior, and collected verbal responses. Mechanisms of thermal and mechanical comfort lead to more pleasant emotions during travel [28]. Moreover, Auliciems described the physiological responses of the human body to thermal conditions as "thermal sensation" and argued that the common use of the term "thermal comfort" in the literature is inadequate to describe unpleasant thermal stimuli to which humans are frequently exposed. He proposed a neutral and comprehensive term to describe physiological and psychological influences together: "thermal perception" [5].

In other study, long-term perception was introduced through the terms 'short-term' and 'memory' [29]. The aim of this study was to investigate correlations between the influences of the respective urban space on thermal perception. The method qualitative techniques (e.g., interviews) and quantitative studies (e.g., micrometeorological measurements of physical parameters and numerical modeling) to obtain a balanced view of the objective and subjective aspects of the thermal perception. Thus, the spatial and material properties of the environment have an influence on thermal perception [5]. The study examined people's perceptions using a structured interview that included questions about their perception of the place in terms of microclimate and perception of the place. Klemm et al. asked participants about thermal perception and spatial perception on a five-point Likert scale from "very cold" to "very hot" to obtain specific information about the descriptors of "ambience" in relation to thermal perception for Dutch urban squares. In this study, people's thermal perceptions correlate with the measurements and simulation results [30].

Another study determined people's individual thermal sensations in spatial zones located in Cairo, Egypt, by conducting interviews in parks during summer and winter. The survey results were presented through descriptive and correlative statistics between PET and the voices on thermal sensations. The results showed a close relationship between the thermal voices and the influence of the sky visibility factor, wind speed, and albedo, based on the microclimatic influence of landscape elements such as the presence of vegetation and fountains [31].

In other seminal study, Ahmad assessed outdoor comfort based on field research through a survey, in the humid tropics. The study discovered factors affecting comfort outdoors for Dhaka and a comfort range of environmental parameters [6].

From an urban design perspective, Zacharias et al. tried to find investigated the relationship between climatic parameters and the human thermal sensation and what significance these parameters have for people's behavior. In this study, a quantitative relationship between microclimate and the use of urban open spaces was described. The results show that, among the microclimatic factors, temperature is the most important variable influencing human well-being [32]. 
Nikolopoulou et al. showed that microclimatic parameters cannot fully explain the large differences between objective and subjective comfort ratings, although they strongly influence the perception of warmth [33].

In another study based on large-scale interviews in within the context of Cambridge City Centre, Nikolopoulou showed that the study of thermal comfort in an urban context does not require a quantitative approach because outdoor comfort conditions are not adequately described. The results of this study show that the design of public spaces requires an understanding of dynamic human parameters and that psychological adaptations such as available choice, environmental stimulation, thermal history, memory effect, and expectations have a greater influence than the thermal environment [26].

In the study, which was conducted in the Nordic city, of Gothenburg, Sweden, Kenz et al. investigated the psychological mechanisms in the evaluation of outdoor places and weather, as well as the significant influences of weather parameters and personal factors such as environmental attitudes and age on the perception and evaluation of urban places [27]. A study in another Nordic city, Tallinn, Estonia investigated optimal commercial building cluster layouts to improve outdoor thermal comfort, assessed using the UTCI index, and indoor thermal comfort and cooling energy use needed to maintain comfort during the warm season [34].

Eliasson et al. used a multidisciplinary and interdisciplinary approach, by focusing on assessing the impact of weather and microclimate on people in outdoor urban environments. The result supports the concept of climate-sensitive planning in future urban design and planning projects [29]. The other study looked at thermal comfort in both dynamic and subjective terms. The study was a four-level assessment framework: physical, physiological, psychological, and social/behavioral. The results led to a general framework for assessing outdoor thermal comfort based on behavioral aspects and outdoor thermal comfort planning [1].

Similarly, Lai et al. assessed outdoor thermal comfort and space utilization in a residential community in Wuhan, central China. The method of the study is both observation of the microclimate through interviews with the residents and observation of the amount and type of activities of the residents [3]. The TSV was used to assess thermal comfort in this study, providing valuable information for the design of outdoor areas in residential communities [3].

\subsection{Originality and Aims of the Study}

Thanks to advances in urban climatology and biometeorological techniques, some detailed microclimatic analyses and thermal comfort assessments have been conducted in the last decade [1]. Therefore, qualitative methods that provide an explicit combination of thermal and spatial information have been developed to link thermal and spatial information about people's perceptions. Based on these findings, new insights can be gained for the design of thermally comfortable urban spaces [5]. There is a lack of understanding of personal parameters, human preferences, microclimatic conditions, as well as urban features that provide comfortable urban space to urban dwellers. The novelty of this study is applying mixed approaches to assess and improve the quality of urban spaces. Thus, the aims of this investigation are as follows:

- To study the role of objective and subjective elements in defining comfort in an urban area;

- To apply qualitative and quantitative research methods in assessing outdoor thermal comfort;

- To explore how and what extent personal factors, weather conditions, environmental conditions, and phisical features of the area can affect comfort sensation.

\section{Methodology}

As different models and tools with varying degrees of complexity have been developed to address the problem of thermal comfort in an urban context, providing a general, com- 
prehensive, insight requires analysis at different levels of complexity and overwhelming engagement with them.

Usually campuses are complex organisms characterised by different activities of people living and working there [35]. We used a mixed-method methodology in this investigation. On one hand, we studied people's thermal preferences during summer in the Tallinn University of Technology (Taltech), Estonia through semi-structured interviews and surveys. On the other hand, we used the well-known ENVI-met CFD software [36,37] to assess outdoor thermal comfort in terms of the PET metric, which is one of the most robust outdoor thermal comfort indices nowadays $[9,13]$.

Figure 1 shows the general framework followed in this study. The qualitative research approach used in the study consists of semi-structured interviews with people who use the campus during the summer season. The quantitative part involves conducting an online survey designed from interviews analyses, as well as observing data on campus, collecting measured climate data on campus, and finally modeling the urban area and conducting CFD simulations. The results of the online survey were used to set simulation case studies: people's personal characteristics, activity levels, and thermal preferences. The measured microclimatic data of the case study area and the city climate data were considered to provide the data for thermal comfort assessment for each sample of the study on each day based on the assumed scenario. The final step in the study is the conclusion and visualization so that all the results and achievements of the study can be used to improve the quality of urban space and provide people with a better-quality urban environment.

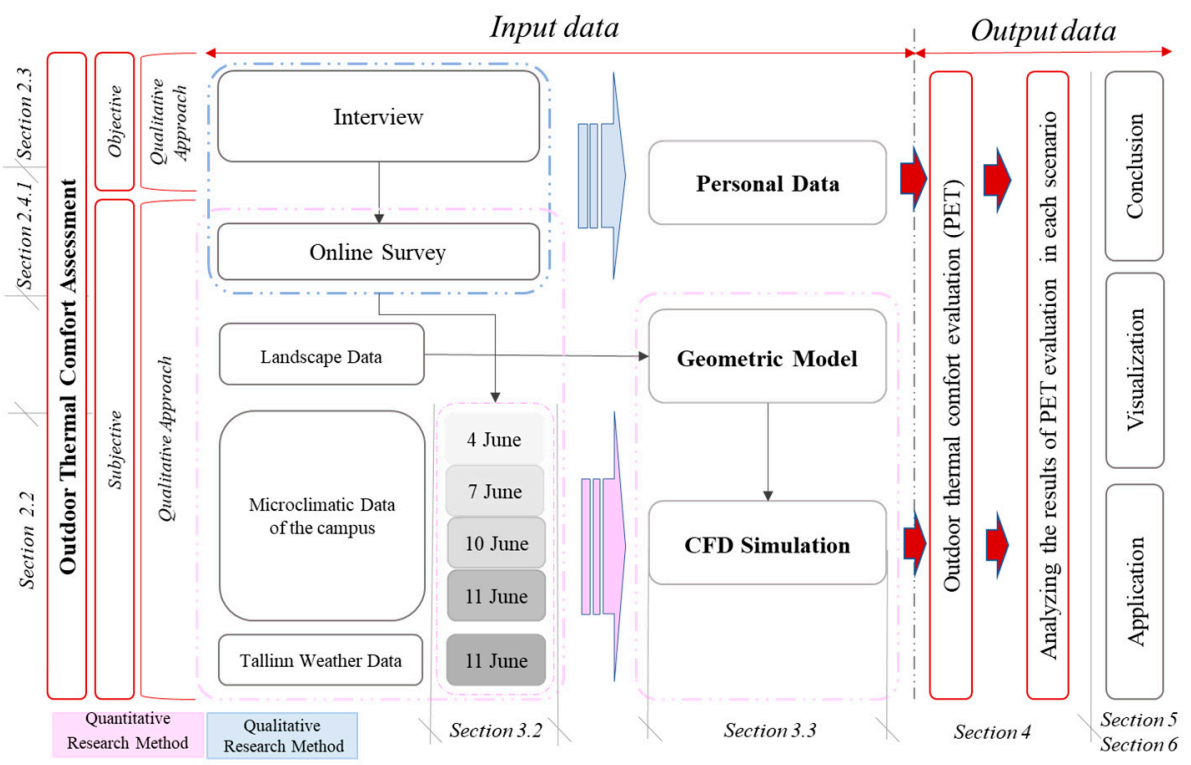

Figure 1. The framework proposed in this investigation.

\subsection{Case Study}

The current case study is located in Tallinn, Estonia (Lat. $59^{\circ} 26^{\prime} \mathrm{N}$ Lon. $24^{\circ} 45^{\prime} \mathrm{E}$ ). Specifically, the Taltech University campus is located in the residential neighborhood of Mustamäe and consists of interconnected buildings surrounded by paved areas, car parks, and green spaces (Figure 2). Tallinn is categorized humid continental climate according to Köppen-Geiger classification Dfb [38]. The medium-density neighborhood is populated by concrete housing blocks with heights from 6 to 10 storey concrete flat blocks, industrial and commercial buildings, and a network of major access roads. In addition, the neighborhood also has green spaces with trees between the buildings but not along the streets [39]. 


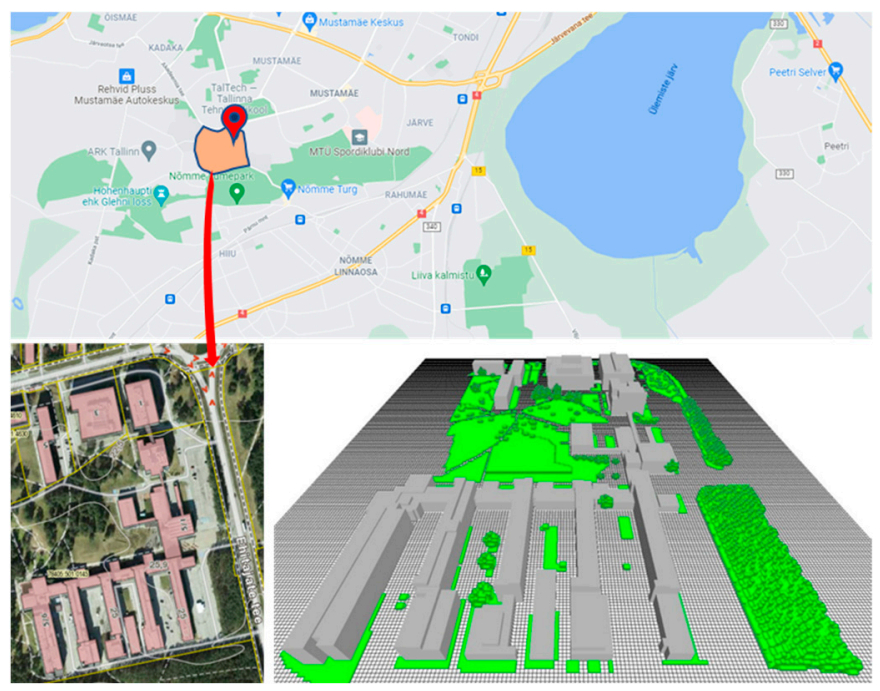

Figure 2. The location of Taltech main campus in Tallinn city map [39], top view of the buildings in the GIS map and the geometric 3D model in ENVI-met.

Thus, the case study encompasses a variety of micro-environments, including buildings, green spaces, parking lots, corridors, sculptures, monuments, benches, lighting elements, etc. In fact, visitors have many opportunities to enjoy the urban environment and engage in different types of activities at different levels. Although the case study hosts people all year round, whether they just enter the buildings or use the surrounding area, people tend to use the campus more in summer when the weather is nice.

\subsection{Climatic Data of the Study}

Tallinn weather data in June 2021 that Figure 3 shows are dry bulb temperature (Min: $7.2{ }^{\circ} \mathrm{C}$, Average: $19.5^{\circ} \mathrm{C}$, Max: $32.2^{\circ} \mathrm{C}$ ), relative humidity (Min: $20 \%$, Average: $66 \%$, Max: $100 \%$ ), and wind speed (Min: 0 m/s, Average: 7.7 m/s, Max: 24 m/s) [38].

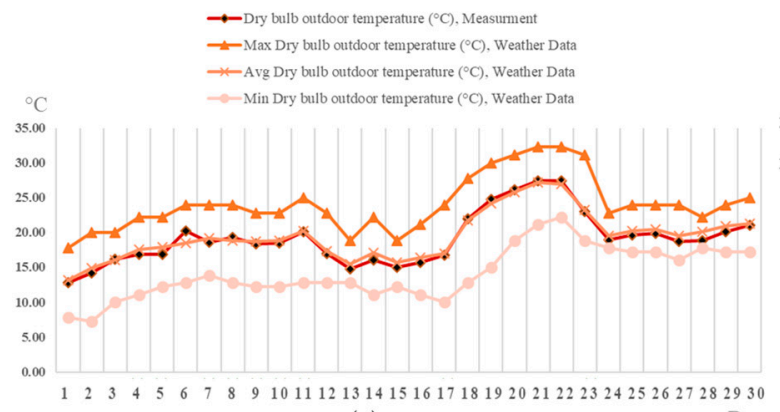

(a)

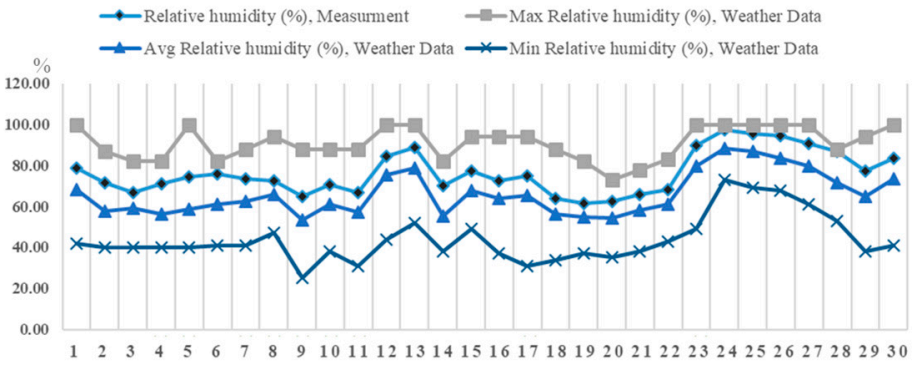

(b)

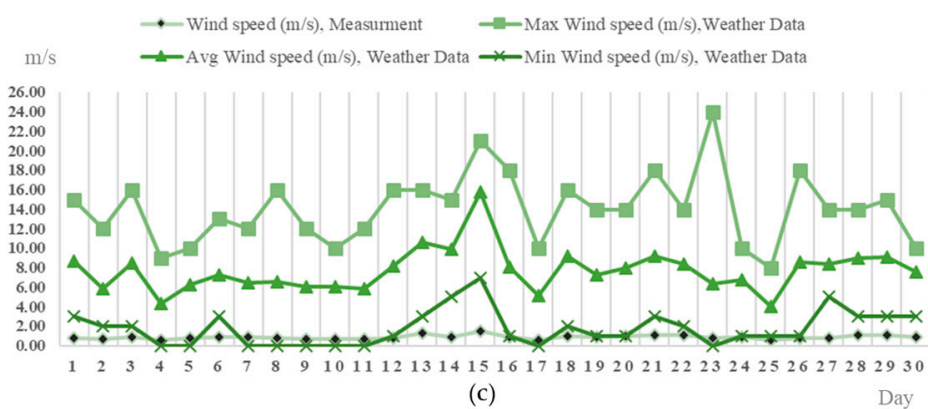

Figure 3. Tallinn, Estonia Weather History, June 2021 [40]. (a) Dry bulb temperature, (b) relative humidity, and (c) wind speed. 
In addition, remote data loggers from nZEB Taltech technological test facility [41] were used to record the environmental profile of the outdoor microclimate and environmental features. Mean radiant temperature $\mathrm{T}_{\mathrm{mrt}}\left({ }^{\circ} \mathrm{C}\right)$ represents the radiative heat load received by a standing human [15]. ENVI-met software that we used for PET assessment is one of the common software for the simulation of Tmrt. Mean radiant temperature $\mathrm{T}_{\mathrm{mrt}}\left({ }^{\circ} \mathrm{C}\right)$ was calculated by the ENVI-met model by summing the contribution of short wave and long wave and long wave radiant fluxes, from the sun, sky, surrounding buildings surfaces, and ground considering the human body view factors of the flux sources. The software needs the obstacle structure of buildings and the global radiation over the whole sky to calculate $\mathrm{T}_{\mathrm{mrt}}$ in two dimensions [42].

The microclimatic data collected in June 2021 (Figure 4), considering the weather conditions in the studied area. The measured microclimatic data are: dry bulb temperature (Min: $12.8^{\circ} \mathrm{C}$, Average: $19.2^{\circ} \mathrm{C}$, Max: $27.5^{\circ} \mathrm{C}$ ), wind direction (Min: $123.3^{\circ}$, Average: $201.3^{\circ}$, Max: $257.8^{\circ}$ ), wind speed (Min: $0.5 \mathrm{~m} / \mathrm{s}$, Average: $0.9 \mathrm{~m} / \mathrm{s}$, Max: $1.5 \mathrm{~m} / \mathrm{s}$ ), and relative humidity (Min: 61.6\%, Average: 76.5\%, Max: 97.4\%).
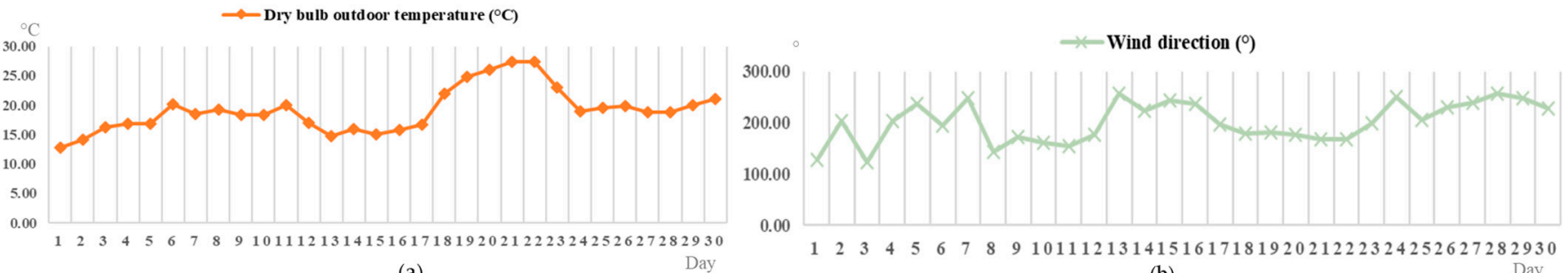

(b)
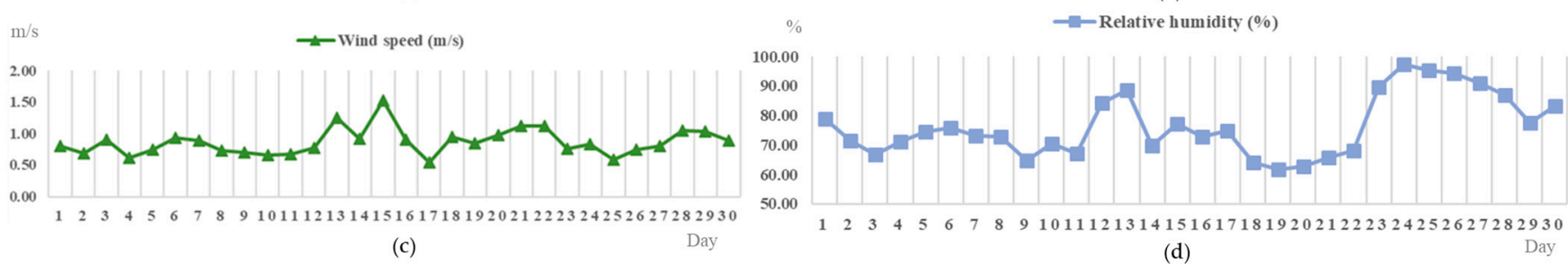

Figure 4. Microclimatic data of the campus, June 2021. (a) Dry bulb temperature, (b) Wind direction, (c) Wind speed, and (d) Relative humidity.

\subsection{Qualitative Study Based on Semi-Structured Interviews}

The present part of the study is grounded on a constructivist methodology because the author accepts that the outdoor thermal sensation of outdoor areas is a complex phenomenon that requires a holistic approach to study it since it depends on each user construction of reality and how they perceive it [39]. Specifically, the authors used the method of the phenomenological semi-structured interview since it could give detailed insights not only of the subjective perception of local weather and outdoor areas of the Tal-Tech Campus but how this is related to the development of outdoor activities and level of clothing $[40,41]$. We did not include pre-set questions related to interviewees' thermal sensation but indirect/open questions that would lead us to understand their preferences in terms of outdoor areas, activities, and climate conditions. With this information we could for one side, design coherent online survey and secondly, identify the worthy case studies to be solved by simulations.

The aim of the designed interview is to address the following main research question (RQ0): which are the most valuable aspects of outdoor thermal sensation during summer according to Tal-Tech Campus users? In order to answer RQ0, three research questions have been formulated (Table 2): 
Table 2. Definition of question blocks used for the interview.

\begin{tabular}{|c|c|}
\hline Block & Questions and Follow-Up Questions \\
\hline $\begin{array}{l}\text { I: Personal } \\
\text { background }\end{array}$ & $\begin{array}{ll}- & \text { Reviewer's introduction } \\
\text { - } & \text { Reminder to the ethic consent given to be recorded } \\
\text { - } & \text { Interviewee's background: gender, nationality, age, education, job } \\
& \text { position, and city of residence }\end{array}$ \\
\hline $\begin{array}{l}\text { II: Introduction to } \\
\text { the topic }\end{array}$ & $\begin{array}{l}\text { - Presentation of the main concept: outdoor thermal comfort and variables } \\
\text { - } \quad \text { Presentation of the main research question (RQ0) } \\
\text { - } \quad \text { Which measurable variable do you appreciate the most? } \\
\text { - } \quad \text { Which measurable variable do you do not care at all? }\end{array}$ \\
\hline $\begin{array}{l}\text { III: Outdoor habits } \\
\text { during summer }\end{array}$ & $\begin{array}{l}\text { - Which months do you consider as part of summer? Why? } \\
\text { - } \quad \text { Do you like outdoor activities? Why? } \\
\text { - } \quad \text { Which outdoor activities do you like to practice during summer? } \\
\text { - } \quad \text { Tell me the most valuable aspect of these outdoor activities. } \\
\text { - How often do you practice them? } \\
\text { - } \quad \text { When and where do you practice them? Do you practice them alone } \\
\quad \text { or in company? } \\
\text { - Which level of clothing do you have during these outdoor activities? }\end{array}$ \\
\hline $\begin{array}{l}\text { IV: Preferred } \\
\text { climate conditions } \\
\text { during summer }\end{array}$ & $\begin{array}{l}\text { - Which are the most comfortable weather conditions for these } \\
\text { preferred outdoor activities? Why? } \\
\text { _ Which would be a bad day to practice these outdoor activities? Why? }\end{array}$ \\
\hline $\begin{array}{l}\text { V: Thermal comfort } \\
\text { during summer in } \\
\text { Taltech Campus }\end{array}$ & $\begin{array}{l}\text { - How often do you go to Taltech Campus? } \\
\text { - } \quad \text { How do you normally go to the Taltech Campus? } \\
\text { - } \quad \text { Which spots of the campus do you visit? How often? Why? } \\
\text { - Could you point in this map which is the best spot to read/working } \\
\text { - } \quad \text { With the laptop/sunbath/cycling/dancing/picnic. } \\
\text { Which level of clothing would you have for these different situations? } \\
\text { - } \quad \text { In overall, could you tell me which parts of the campus during } \\
\text { summer is the most/less attractive to you? Why? }\end{array}$ \\
\hline
\end{tabular}

RQ1: How frequently do Taltech Campus users actually use outdoor areas and why?

RQ2: Which areas of the campus are preferred for different outdoor activities and why?

RQ3: Which are the optimal weather conditions according to Taltech Campus users for different outdoor activities in the Campus?

The interview has been structured in five thematic blocks (Table 2). Block I contains questions that aim to know specific details of the interviewee's personal background such as nationality, age, and city of residence. The objective of Block II is to introduce the re-search topic as well as to discover the valuable climate conditions for the interviewee and to discover how familiar the interviewee is with the topic. Blocks III contains questions that aims to know the interviewee's outdoor habits during summertime in Estonia. The objective of Block IV is to know about the preferred climate conditions during summer in Estonia. Finally, Block V aims to discover the relationship between the interviewee and the Taltech Campus area: visit frequency, outdoor activities, preferred spots, etc.

Ten interviewees with different nationalities and backgrounds were selected. They could give insights to answer RQ0, since they are whether Master/doctoral students or research staff in Taltech. The interviews were conducted from 2 July 2021 until 31 September 2021 with the sign of the ethics consent form to protect their privacy [43]. The communication ways were e-mail, posters, and social media such as Facebook posts. The qualitative data collection consisted in the production of transcriptions from each interview [44] and its study with the well-known thematic analysis [45]. 


\subsection{Quantitative Study}

\subsubsection{Survey Study}

We used survey technique to obtain meaningful subjective information from a diverse profiles of Taltech Campus users to set up realistic people cases. The online surveys (the structure of the survey is in Appendix A) were answered by 40 people from September to November 2021. The structure of the survey was built based on the results and outcomes from in depth interview and relevant factors of the metric PET to evaluate outdoor thermal comfort as Figure 1 in the methodology section shows. For the design of the survey, we considered the information explained from the Section 6. Qualitative study based on semi-structured interviews. The online survey had valid 26 answers. There were three thematic blocks as the interview: personal background, preferred weather conditions during summer, and Taltech Campus (Table 3).

Table 3. Definition of question blocks used for the interview.

\begin{tabular}{ll}
\hline Thematic Block & Requested Information \\
\hline Personal background & $\begin{array}{l}\text { Place of birth, age, gender, level of education, current occupation, } \\
\text { height, weight, physical disability, chronic disease, number of } \\
\text { summer periods in Estonia, summer months. }\end{array}$ \\
\hline $\begin{array}{l}\text { Preferred summer } \\
\text { weather conditions }\end{array}$ & $\begin{array}{l}\text { Outdoor activities in summer, preferred level of: solar radiation, } \\
\text { temperature, relative humidity, precipitation, wind speed, and } \\
\text { sky type. }\end{array}$ \\
\hline & $\begin{array}{l}\text { Use months, distance from home, used outdoor areas, less } \\
\text { attractive outdoor areas, weekly hours spent in outdoor areas, } \\
\text { practised outdoor activities in the campus, main limitation of the } \\
\text { actual outdoor areas. }\end{array}$ \\
\hline
\end{tabular}

Although results from survey analysis cannot be generalized because of the small sample size, we used these results to set up diverse and realistic campus users' profiles in order to study how to improve their outdoor thermal comfort during summer in Taltech Campus. In this way, we demonstrated how to apply this mixed-method approach to any case study. Statistical analyses of the survey are detailed in Section 3.2.

\subsubsection{Modeling and Simulation Process}

This part of the study consisted of geometric modeling and CFD simulation. First, all the data of the landscape, buildings, elements, and furniture of the Taltech campus are collected based on on-site observations. Then, the details of the studied area were used for geometric modeling in the ENVI-met software environment, a three-dimensional microscale numerical model that calculates the distribution of heat, momentum, and humidity in the urban environment according to the equations of thermo/fluid dynamics and thermodynamics [46]. We conducted CFD simulations to define the PET-based comfort range for each representative case (i.e., clothing insulation, metabolic rate, physical attributes, etc.) study obtained from statistical analyses from online surveys (built from interviews analyses). The ENVI-met environmental simulation software uses a microclimate model based on the fundamental laws of fluid dynamics and thermodynamics [37]. The simulation process was conducted with ENVI-met to prepare CFD simulations for each day according to the defined scenarios based on the results of the weather preferences of the people in the survey to define the thermal comfort range of the participants based on PET indices.

The thermal comfort assessment was calculated using ENVI-met. In the final stage, using the results of different thermal comfort based on the results of the survey about personal characteristics, activity level, clothing level and preferred weather conditions, different parts of the campus were evaluated to indicate the comfort level and characteristics of each part. Clothing insulation has a major impact on thermal comfort as it affects heat loss and thus thermal balance [47]. In this study, the mean the values for metabolic rate are 
65 (class resting), 100 (class low), 165 (class moderate), 230 (class high), and 290 (class very high) $\mathrm{W} / \mathrm{m}^{2}$ for resting, sitting at ease/standing, sustained hand/arm work, and intense work activities, respectively [47].

\section{Results}

\subsection{Interviews Analyses}

The $60 \%$ of the interviews were conducted virtually due to the pandemic situation as well as availability issues. The interviewees between 23-56 years old were from nine different countries. The $80 \%$ of the interviewees were males. There was one senior researcher, one master student and the rest were PhD students from Taltech. The main conclusions after thematic analyses of the interviews are the following:

- June and July were the commonly recognised month as part of the summer.

- Among the most common features of the outdoor activities during summer in Estonia, the interviewees used the following terms: sun, nature, fresh air, and daylight. The preference for a specific spot in the campus depends mainly on the level of nature, accessibility, protection against the sun, the presence of shades, and presence of places comfortable for sitting and working with laptops, laptop battery, climate conditions, and level of privacy. The level of clothing depends mainly on the climate conditions and the type of outdoor activity, but generally they prefer to wear short-sleeves/light clothes in summer (answer to RQ0).

- According to them a perfect summer day would have a temperature between $20^{\circ} \mathrm{C}$ and $25^{\circ} \mathrm{C}$ with a gentle breeze and almost clear sky (answer to RQ3).

- They consider very hot and humid/stormy days as the less desired ones during summer in Estonia.

- In terms of level of clothing, the $60 \%$ of the interviewees like wearing short clothes during summer. The $40 \%$ of the interviewees find normal to wear light clothes during summer.

- The half of the interviewees live near the campus so they normally go to the campus by walk. The rest of them would go by car, bus, or even e-scooter. The frequency of visit depends on each person and where they live and work.

- Among $70 \%$ of the interviews use the outdoor areas of the campus.

Their favorite areas of the campus are colored in blue in Figure 5, and the less attractive areas are colored in red in Figure 6. The most attractive areas of the campus are concentrated around the inner courtyard of the Taltech campus (answer to RQ2). The vegetation present in these areas and connectivity with majority of main buildings of the university and student houses make this inner courtyard very attractive because of its multi-functionality: several type of activities can be done in this area. In addition, the wooden area next to the U06 building is valued for some interviewees to go cycling, picnicking, or dancing because of the contact with the rough nature and privacy. The less attractive areas of the Taltech Campus are mainly areas with lack of green areas such as the parking lots, dusty pedestrian zones next to Mektory buildings, or noisy areas due to the heavy traffic of the avenue Akadeemia tee. In addition, some interviewees highlighted the thermal discomfort of the garden between student dormitories due to the poor circulation of fresh air and the reflected radiation during summer.

The main areas to develop different activities in the campus considered by the interviewees are concentrated in the main inner courtyard of the Campus, at the same time, parking lots have big potential of improvement. Therefore, the zone of the campus that we aim to study the outdoor thermal comfort because of its potential use and improvement is shown in Figure 5. 


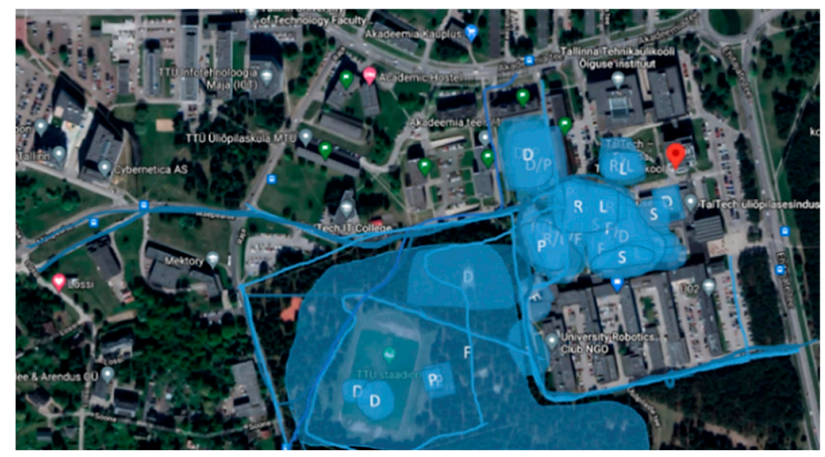

Figure 5. Taltech campus map with colored preferred areas for different outdoor activities. $\mathrm{R}=$ reading a book, $\mathrm{L}=$ working with the laptop, $\mathrm{D}=$ dancing, $\mathrm{S}=$ sunbathing, $\mathrm{P}=$ picnic, and $\mathrm{F}=$ favorite spot. Blue lines represent preferred cycling routes [48].

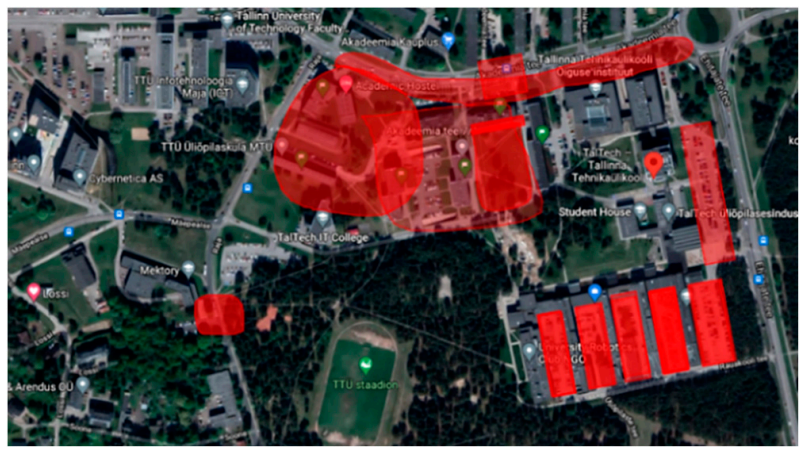

Figure 6. Taltech campus map with colored less attractive areas by the interviewees [48].

The less attractive areas of the Taltech Campus are mainly areas that lack of green space such as the parking lots, dusty pedestrian zones next to Mektory building or noisy areas due to the heavy traffic of the avenue Akadeemia tee. In addition, some interviewees highlighted the thermal discomfort of the garden between student dormitories due to the poor circulation of fresh air and the reflected radiation during summer.

The main areas to develop different activities in the campus considered by the interviewees are concentrated in the main inner courtyard of the Campus, at the same time, parking lots have big potential of improvement. Therefore, the zone of the campus that we aim to study the outdoor thermal comfort because of its potential use and improvement is shown in Figure 7.

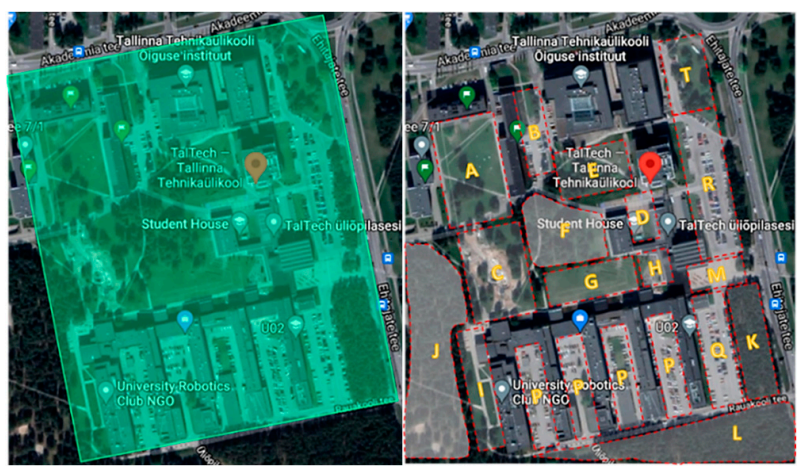

Figure 7. Taltech campus area of study according to the interview's analyses. In the left subfigure, the green zone represents the most critical area of the campus because includes preferred areas and less attractive areas which can be improved in the future. The right subfigure shows the main area divisions referred by the interviewees [48]. 
The findings obtained from the interviews might contain bias due to the uneven gender balance. Moreover, answers collected virtually from the same interviewee could be different from those collected from face-to-face interviews. The main reasons of these bias sources could be the pandemic situation, interviewees' health, vacation periods, and will to improve the campus in summer, level of applicability of the findings agreed by the practitioners, etc.

\subsection{Survey Analyses}

The aim of this section is to analyze the survey responses and define the relevant case studies for calculating outdoor thermal comfort. To define these samples, the following analyses are conducted:

First, we highlight the most important features to define campus use samples that have been optimized using the information from the interview analyses. To this end, we developed a simple statistical analysis to define representative profiles of campus users by considering the correlation between variables. In addition, we define the relevant weather conditions and a summer month based on the survey responses. We classify the preferred outdoor activities on campus based on metabolic rates.

Therefore, in order to determine a more accurate PET that is close to a person's thermal sensation, it is important to consider all the important parameters.

Based on the data obtained from the survey, an initial assessment of PET was made by evaluating the CFD model of 4 June in the ENVI-met environment. This step aims to find out the main characteristics and variables that are meaningfully related to PET as thermal comfort indices in the study and should be considered in defining the samples of the study with different definitions. Then, an initial sample of 30 people who use the campus in summer was drawn based on various characteristics-e.g., gender, age, clothing level, activity level (influence on metabolism), height and weight (influence on body surface area). The analysis of BIO-met benefits from the microclimatic data of the campus at 16:00 on the CFD simulation results of 4 June, the first day according to the study scenario.

In this part, Pearson correlation was applied, which shows the correlated variables and PET. According to the definition of Pearson correlation, the values close to 1 show perfect correlation and the low correlated ones close to 0 . On one hand, according to Figure 8 , the most significant variables correlated with PET are metabolic rate, $\mathrm{M}$ (the results of activity level and weight and height) and $\mathrm{I}_{\mathrm{cl}}$ (the level of clothing). On the other hand, gender and age are not such strongly correlated with PET, hence, we do not analyze survey data separately according to these two variables. Therefore, during the simulation process, we selected the following personal characteristics: clothing insulation $\left(\mathrm{I}_{\mathrm{cl}}\right)$, metabolic rate, weight, height, and age and gender-where we assumed a 30-year-old male in all samples.

We analyzed answers from participants who used somehow the outdoor areas of the campus and facilitated relevant personal information (28 participants): age, gender, weight, and height. There were $46 \%$ females and $54 \%$ males. Moreover, $46 \%$ of participants are Estonian, 14\% from Iran, and the rest of participants are from different countries such as Philippines, Spain, Pakistan, Indonesia, Russia, and Mexico. Participants' occupation was very diverse: from assistant professors to bachelor students. Most of participants (95\%) do not have chronic disease and none of the respondents had a physical disability. The minimum, mean, and maximum age are 20,30, and 44 years old, respectively.

Firstly, we calculated the body mass index (BMI) (weight in $\mathrm{kg}$ )/(height in $\mathrm{m}^{2}$ ) from height and weight data (Figure 8). Secondly, we calculated representative values of the studied sample: minimum, Q1, Q2, Q3, and maximum values (Table 4) of relevant factors of the PET metric. In addition, we selected the closest weights related to each of the representative values of BMI values from survey answers. Finally, we determined the height from these representative BMI and weight values (Table 4). Furthermore, we defined 5 BMI-driven subject profiles (Table 4). As we mentioned, we fixed age and gender variables. According to our survey answers, the gender and age of these five profiles could be equivalent to a 30-years old male, respectively. 


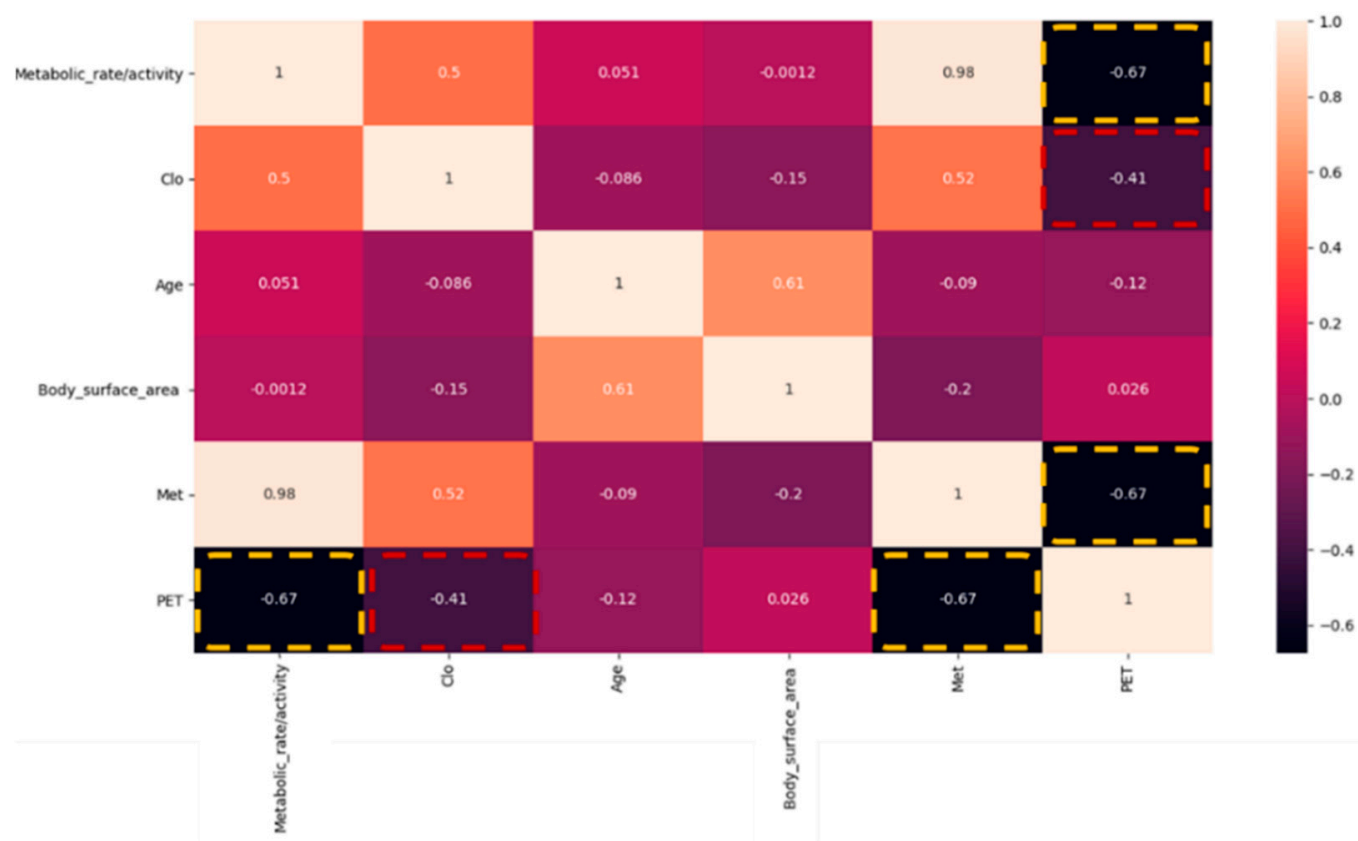

Figure 8. Dependency values between PET metric and factors in outdoor thermal comfort.

Table 4. Classification of metabolic rates by activity.

\begin{tabular}{|c|c|c|c|c|}
\hline Value & BMI $\left(\mathrm{kg} / \mathrm{m}^{2}\right)$ & Weight (kg) & Height (m) & Profile ID \\
\hline Minimum & 17.99 & 52 & 1.70 & 1 \\
\hline Q1 & 20.10 & 67 & 1.83 & 2 \\
\hline$\widehat{\mathrm{Q} 2}$ & 23.52 & 68 & 1.70 & 3 \\
\hline Q3 & 25.78 & 83 & 1.79 & 4 \\
\hline Maximum & 31.55 & 101 & 1.79 & 5 \\
\hline
\end{tabular}

The months in which the participants used more the Taltech Campus are May (92.9\%) and September (71.4\%) (Figure 9). However, May and September are considered as part of the summer period in Estonia by only a $7.1 \%$ and $3.6 \%$ of the participants, respectively (Figure 10). Although July is considered the summer month by most participants (96.4\%), only a $53.6 \%$ of the participants used the outdoor areas of the campus against $71.4 \%$ related to June. Furthermore, we select June as the most relevant summer month by our studied sample because of its consideration of summer month and frequency of use of the outdoor areas of the campus.

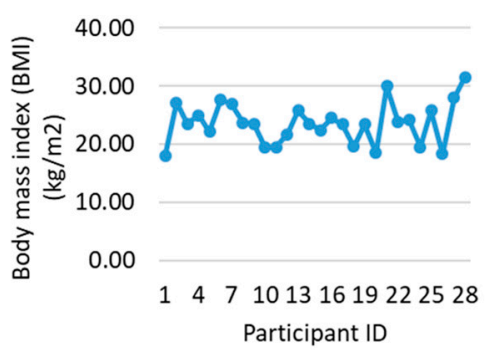

(a)

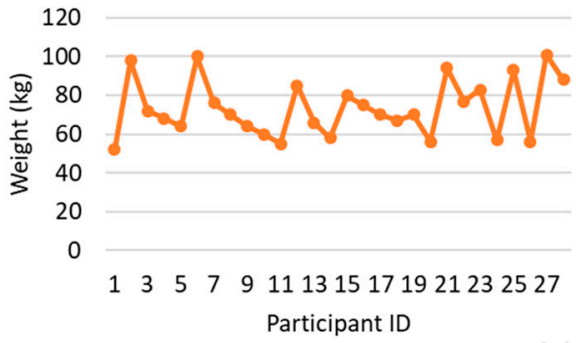

(b)

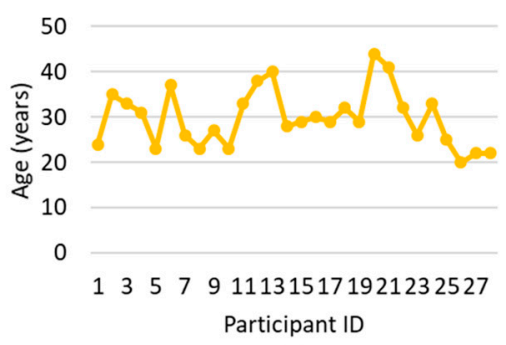

(c)

Figure 9. Participants' body mass index (BMI) (a), weight (b), and age (c). 


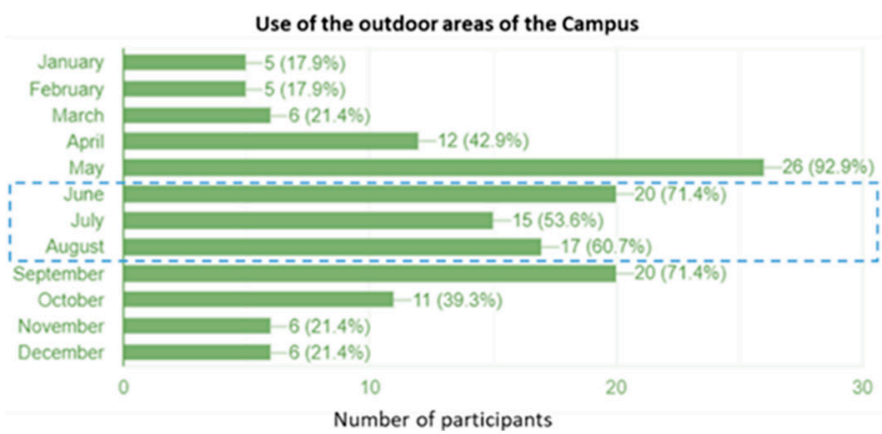

(a)

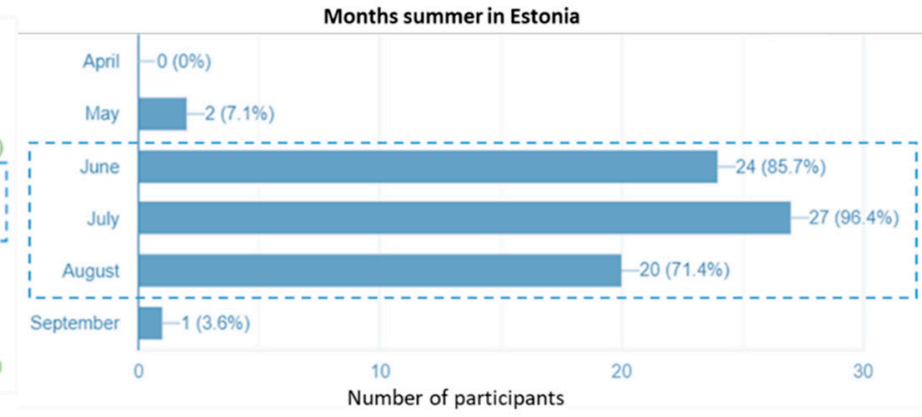

(b)

Figure 10. Months in which participants use the Taltech Campus (a) and considered summer months (b).

In terms of preferred weather conditions (Figure 10), the overall perfect summer day according to most participants include the following weather conditions: medium solar radiation $(75 \%)(\mathrm{Uvi}=3-5)$ (Figure $11 \mathrm{a})$, medium temperature $(60.7 \%)\left(20-25.9^{\circ} \mathrm{C}\right)$ (Figure $11 \mathrm{~b})$, medium relative humidity $(57.1 \%)(40-60 \%)$ (Figure $11 \mathrm{c})$, no rain $(82.1 \%)$ (Figure 11d), gentle breeze (wind speed $<4 \mathrm{~m} / \mathrm{s}$ ) (Figure 11e), and full clear sky (50\%) (Figure 11f). Furthermore, we consider these weather conditions in the next simulationbased CFD analysis as the input weather data based on measured campus microclimatic data and Tallinn climatic data. Different weather conditions than these ones might not encourage participants to spend time in the outdoor areas of the Campus, and therefore the analysis of the outdoor thermal comfort is not as relevant as under preferred weather conditions.

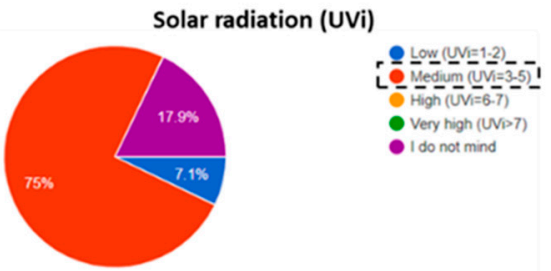

(a)

Relative humidity (\%)

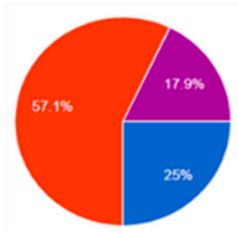

(c)

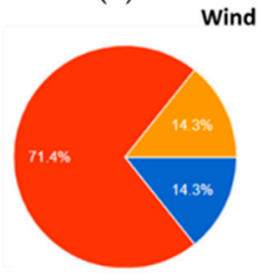

(e)

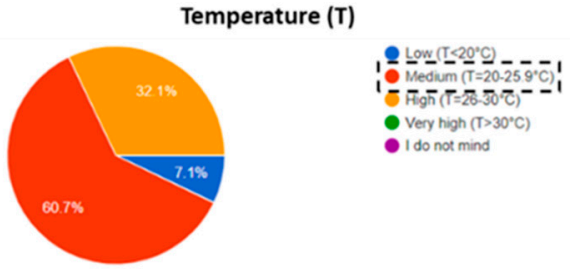

(b)

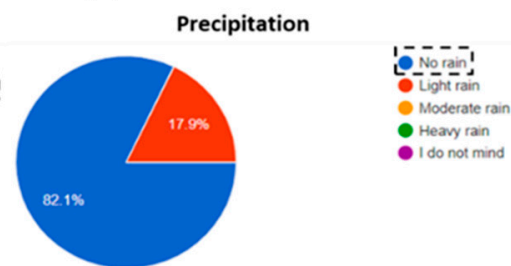

(d)

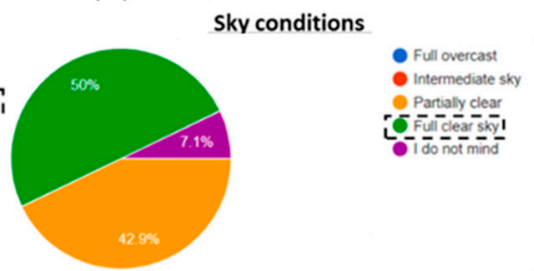

(f)

Figure 11. Preferred levels of weather conditions according to survey participants: solar radiation in terms of UV-index (UVi) (a), outdoor dry bulb temperature (T) (b), relative humidity (\%) (c), precipitation (d), wind speed $(\mathrm{m} / \mathrm{s})(\mathbf{e})$, and sky condition (f). The classes used in these survey questions were designed according to interviews' answers (Section 3.1).

The scenarios that define the days of the CFD simulation process and the climate data are based on two sources. First, on the preferences of the respondents in the survey and the 
days they described as most thermally comfortable conditions in the Tallinn climate data (Table 5), and second, on the same preferred conditions in days based on the Taltech campus microclimatic data temperature $20^{\circ} \mathrm{C}$, wind speed $0.7 \mathrm{~m} / \mathrm{s}$ and relative humidity $67 \%$.

Table 5. Selected days for CFD simulation, based on the survey. Microclimatic data of Taltech campus in June 2021.

\begin{tabular}{|c|c|c|c|c|c|c|c|}
\hline Date & $\begin{array}{c}\text { Air Dry Bulb } \\
\text { Temperature }\left({ }^{\circ} \mathrm{C}\right)\end{array}$ & $\begin{array}{l}\text { Solar Radiation } \\
\text { (UV-Index) }\end{array}$ & $\begin{array}{l}\text { Wind Speed } \\
(\mathrm{m} / \mathrm{s})\end{array}$ & $\begin{array}{c}\text { Wind } \\
\text { Direction }\left({ }^{\circ}\right)\end{array}$ & RH (\%) & $\begin{array}{l}\text { Precipitation } \\
\text { (Yes/No) }\end{array}$ & Sky Type \\
\hline 4 June & $20-22$ & 5 & 3.3 & 90 & $46-75$ & No & Passing clouds \\
\hline 7 June & $21-23$ & 5.2 & 4.2 & 90 & $48-77$ & No & Passing clouds \\
\hline 10 June & $22-23$ & 5.5 & 4. 2 & 90 & $46-82$ & No & Passing clouds \\
\hline 11 June & $24-25$ & 5.7 & 3.9 & 90 & $35-85$ & No & Passing clouds \\
\hline
\end{tabular}

Once the profiles of the individuals and the weather conditions are established, the most common metabolic rates associated with common outdoor activities on campus need to be defined. There are different classes of activities depending on the metabolic rate (Table 6).

Table 6. Classification of metabolic rates by activity developed in the Taltech campus [19].

\begin{tabular}{|c|c|c|c|c|}
\hline Class & $\begin{array}{l}\text { Metabolic } \\
\text { Rate }\left(W / m^{2}\right)\end{array}$ & Example & Outdoor Activities (Number of Times Selected) & $\begin{array}{l}\text { Selected } \\
\text { Times }\end{array}$ \\
\hline Resting & 65 & Resting & Chilling out in outdoor areas (14), read a book (6) & 20 \\
\hline Low & 100 & Sitting at ease/standing & Go picnic (9), e-scooter (3) & 12 \\
\hline Moderate & 165 & Sustained hand/arm work & Hang out (18), walking (18), go camping (1) & 37 \\
\hline High & 230 & Intense work & Jogging (8), hiking (3), table tennis (2), cycling (1) & 14 \\
\hline Very high & 290 & $\begin{array}{l}\text { Very intense to maximum } \\
\text { activity }\end{array}$ & $\begin{array}{l}\text { Running (5), beach-volleyball (1), badminton (1) } \\
\text { street workout (3), basketball (3), orienteering (1) }\end{array}$ & 14 \\
\hline
\end{tabular}

According to the outdoor activities developed in the outdoor areas of the campus by the survey participants, activities with very low metabolic rate $\left(65 \mathrm{~W} / \mathrm{m}^{2}\right)$ such as "chilling out" or "read a book" were selected by the participants 20 times. Moreover, activities with moderate metabolic rate $\left(165 \mathrm{~W} / \mathrm{m}^{2}\right)$ such as "hang out", "walking", or "go camping" were selected 37 times in total. On the other hand, "low", "high", and "very high" outdoor activities were not such popular for the participants. This could be due to the limited space and ground conditions in the part of the campus analyzed (Figure 11) for certain activities such as e-scooter, hiking, cycling, running, beach-volleyball, badminton, street workout, basketball, etc.

Therefore, we consider "very low" and "moderate" level of activities as the most common ones practiced by the participants in the outdoor areas of the campus during summer.

Input Elements to Assess Thermal Comfort Based on the Survey

Some of the parameters that lead to a person feel thermally comfortable are inherent in the characteristics of a space, while others are more personal to the environment. The complexity of these relationships means that none of them follow a simple cause-andeffect situation [33]. The data that defined the sample of thermal comfort assessment studies are based on survey information and literature reviews [19,49-51]. According to participants' answers the preferable level of clothing during summer could vary from swim trunks/bikini with sandals and a cap to short sleeved clothes. Despite of the influence of the body movements and air action on clothing thermophysical properties [52], we used a simplified approach based on static $\mathrm{I}_{\mathrm{cl}}$ values. Specifically, the static $\mathrm{I}_{\mathrm{cl}}$ values, meaning the $\mathrm{I}_{\mathrm{cl}}$ value for a person wearing a bikini (upper and lower part) or swim trunks ( 0.1 and 0.3 clo, respectively) $[18,19,49]$. Moreover, we considered a $\mathrm{I}_{\mathrm{cl}}$ of 0.5 clo as an average value to represent light summer short-sleeve clothes according to Blazejczyk [49]. 
The spatial distribution of outdoor thermal comfort in terms of the metric PET is calculated via simulation for 20 defined cases ( 5 BMIs $\times 2$ Icls $\times 2$ Ms) study under preferred summer conditions (Figure 11) in Section 3.2.

Finally, we define 20 cases ( 5 BMIs $\times 2 \mathrm{I}_{\mathrm{cl}} \mathrm{s} \times 2 \mathrm{Ms}$ ) of interest that represent our analyzed sample. As can be seen in Table 7, we can consider a 30-year-old man with different BMI conducting activities with very low $\left(65 \mathrm{~W} / \mathrm{m}^{2}\right)$ and moderate $\left(165 \mathrm{~W} / \mathrm{m}^{2}\right)$ metabolic rates while wearing different summer outfits ( $\mathrm{I}_{\mathrm{cl}}$ of 0.1 and 0.5 clo) under different climate conditions. The average PET assessed for each case study experience under the supposed microclimatic data in the campus.

Table 7. Definition of the cases study considered for the calculation of outdoor thermal comfort using the PET metric under preferred weather conditions, the level of activity, and $\mathrm{I}_{\mathrm{cl}}$.

\begin{tabular}{|c|c|c|c|c|c|c|c|c|c|}
\hline \multirow[b]{3}{*}{ Case ID } & \multirow{2}{*}{\multicolumn{3}{|c|}{ Personal Data of Samples }} & \multicolumn{6}{|c|}{ Average PET $\left({ }^{\circ} \mathrm{C}\right)$ in the Campus Area } \\
\hline & & & & \multicolumn{5}{|c|}{ Campus Microclimatic Data } & \multirow{2}{*}{$\begin{array}{c}\text { Tallinn } \\
\text { Climatic Data } \\
11 \text { June }\end{array}$} \\
\hline & $\begin{array}{l}\text { Weight } \\
\text { (kg) }\end{array}$ & $\begin{array}{l}\text { Height } \\
\text { (m) }\end{array}$ & $\begin{array}{c}\text { Metabolic } \\
\text { Rate }\left(\mathrm{W} / \mathrm{m}^{2}\right)\end{array}$ & $\mathrm{I}_{\mathrm{cl}}(\mathrm{clo})$ & 4 June & 7 June & 10 June & 11 June & \\
\hline p1m1c1 & 52 & 1.70 & 65 & 0.1 & 43 & 44 & 30.2 & 47.2 & 43.9 \\
\hline $\mathrm{p} 2 \mathrm{~m} 1 \mathrm{c} 1$ & 67 & 1.83 & 65 & 0.1 & 36 & 38.2 & 49.8 & 40.1 & 43.6 \\
\hline $\mathrm{p} 3 \mathrm{~m} 1 \mathrm{c} 1$ & 68 & 1.70 & 65 & 0.1 & 42.3 & 42.7 & 40.3 & 48.2 & 44.1 \\
\hline $\mathrm{p} 4 \mathrm{~m} 1 \mathrm{c} 1$ & 83 & 1.79 & 65 & 0.1 & 31.3 & 41.7 & 41.3 & 44.8 & 44.2 \\
\hline p5m1c1 & 101 & 1.79 & 65 & 0.1 & 35.7 & 37.1 & 29.3 & 37.2 & 43.8 \\
\hline p1m2c1 & 52 & 1.70 & 165 & 0.1 & 39.3 & 38.7 & 38.7 & 39.9 & 28.6 \\
\hline $\mathrm{p} 2 \mathrm{~m} 2 \mathrm{c} 1$ & 67 & 1.83 & 165 & 0.1 & 40.1 & 37 & 38.5 & 37.6 & 29.2 \\
\hline p3m2c1 & 68 & 1.70 & 165 & 0.1 & 29.5 & 35.6 & 39.4 & 39.7 & 40.3 \\
\hline $\mathrm{p} 4 \mathrm{~m} 2 \mathrm{c} 1$ & 83 & 1.79 & 165 & 0.1 & 45.6 & 38.4 & 39.1 & 36.3 & 40.3 \\
\hline p5m2c1 & 101 & 1.79 & 165 & 0.1 & 38.8 & 39.1 & 29.7 & 39.6 & 39.5 \\
\hline $\mathrm{p} 1 \mathrm{~m} 1 \mathrm{c} 2$ & 52 & 1.70 & 65 & 0.5 & 39.4 & 33.8 & 39.1 & 46.6 & 42.2 \\
\hline $\mathrm{p} 2 \mathrm{~m} 1 \mathrm{c} 2$ & 67 & 1.83 & 65 & 0.5 & 42.6 & 40.1 & 44.5 & 45.9 & 37.9 \\
\hline p3m1c2 & 68 & 1.70 & 65 & 0.5 & 33 & 37 & 27 & 46.4 & 29.8 \\
\hline $\mathrm{p} 4 \mathrm{~m} 1 \mathrm{c} 2$ & 83 & 1.79 & 65 & 0.5 & 43.6 & 37.9 & 25.4 & 45.8 & 42.9 \\
\hline p5m1c2 & 101 & 1.79 & 65 & 0.5 & 33.7 & 30.4 & 39.7 & 47.7 & 42.9 \\
\hline p1m2c2 & 52 & 1.70 & 165 & 0.5 & 38.8 & 38.3 & 38.3 & 39.2 & 40.1 \\
\hline $\mathrm{p} 2 \mathrm{~m} 2 \mathrm{c} 2$ & 67 & 1.83 & 165 & 0.5 & 36.4 & 36.4 & 30.5 & 37.5 & 38.4 \\
\hline $\mathrm{p} 3 \mathrm{~m} 2 \mathrm{c} 2$ & 68 & 1.70 & 165 & 0.5 & 30.1 & 37.6 & 29.6 & 30.6 & 39.9 \\
\hline $\mathrm{p} 4 \mathrm{~m} 2 \mathrm{c} 2$ & 83 & 1.79 & 165 & 0.5 & 38.3 & 31.7 & 39 & 39 & 39.4 \\
\hline p5m2c2 & 101 & 1.79 & 165 & 0.5 & 38.4 & 37.8 & 35.2 & 38.6 & 41.3 \\
\hline
\end{tabular}

\subsection{CFD Simulation Analysis and Results}

Since the study focuses on comparing the objective personal and climatic data with people's subjective thermal perception data, needs, and preferences, this section considers all the collected and analyzed survey data from Table 8 to define the thermal comfort of people with different activity levels, metabolic rates, clothing levels, and body surfaces in PET indices in the studied area.

In the next step, the data of each person considered to evaluate PET on four days based on the microclimatic data of the studied area on 4, 7, 10, and 11 June 2021 and the weather data of Tallinn on 11 June 2021 using the BIO-met function of ENVI-met software as a post-processor tool to calculate the human thermal comfort indices from the output files of ENVI-met model.

The simulation of CFD was conducted for each date at 16:00 (the hottest time of the day based on people's weather preferences) and the atmospheric data were used as input data to evaluate PET for each sample in the study. 
Table 8. Evaluation of PET range in different samples, based on the microclimatic data.

\begin{tabular}{|c|c|c|c|c|c|c|c|}
\hline $\begin{array}{l}\text { The Average } \\
\text { PET Range }\end{array}$ & Type of Activity & $\begin{array}{c}\mathrm{I}_{\mathrm{cl}} \\
\text { (clo) }\end{array}$ & $\begin{array}{l}\text { Height } \\
\text { (cm) }\end{array}$ & $\begin{array}{l}\text { Weight } \\
\text { (kg) }\end{array}$ & $\begin{array}{c}\text { Dry Bulb } \\
\text { Temperature } \\
\left({ }^{\circ} \mathrm{C}\right)\end{array}$ & $\begin{array}{c}\text { Wind } \\
\text { Speed } \\
(\mathrm{m} / \mathrm{s})\end{array}$ & $\begin{array}{c}\text { Relative } \\
\text { Humidity } \\
\text { (\%) }\end{array}$ \\
\hline \multirow{2}{*}{$\begin{array}{l}\text { Slightly warm } \\
\left(23-29^{\circ} \mathrm{C}\right)\end{array}$} & Resting & 0.5 & 170 & 68 & \multirow[b]{2}{*}{$22-23$} & \multirow[b]{2}{*}{4.17} & \multirow[b]{2}{*}{$46-82$} \\
\hline & Resting & 0.5 & 179 & 83 & & & \\
\hline \multirow{10}{*}{$\begin{array}{c}\text { Warm } \\
\left(29-35^{\circ} \mathrm{C}\right)\end{array}$} & Resting & 0.1 & 179 & 83 & \multirow{3}{*}{$20-22$} & \multirow{3}{*}{3.33} & \multirow{3}{*}{$46-75$} \\
\hline & Resting, sustained arm or hand work & $0.1,0.5$ & 170 & 68 & & & \\
\hline & Resting & 0.5 & 179 & 101 & & & \\
\hline & Resting & 0.5 & 170 & 52 & \multirow{3}{*}{$21-23$} & \multirow{4}{*}{4.16} & \multirow{4}{*}{$48-77$} \\
\hline & Resting & 0.5 & 179 & 101 & & & \\
\hline & Sustained arm or hand work & 0.5 & 179 & 83 & & & \\
\hline & Resting, sustained arm or hand work & $0.1,0.5$ & 170 & 52,68 & \multirow{3}{*}{$22-23$} & & \\
\hline & Resting, sustained arm or hand work & $0.1,0.5$ & 179 & 101 & & \multirow[t]{2}{*}{4.17} & \multirow[t]{2}{*}{$46-82$} \\
\hline & Sustained arm or hand work & 0.5 & 183 & 67 & & & \\
\hline & Sustained arm or hand work & 0.5 & 170 & 68 & $24-25$ & 3.88 & $35-85$ \\
\hline \multirow{18}{*}{$\begin{array}{c}\text { Hot } \\
\left(35-41^{\circ} \mathrm{C}\right)\end{array}$} & Resting, sustained arm or hand work & $0.1,0.5$ & 183 & 67 & \multirow{4}{*}{$20-22$} & \multirow{4}{*}{3.33} & \multirow{4}{*}{$46-75$} \\
\hline & Resting, sustained arm or hand work & $0.1,0.5$ & 179 & 101 & & & \\
\hline & Resting, sustained arm or hand work & $0.1,0.5$ & 170 & 52 & & & \\
\hline & Sustained arm or hand work & 0.5 & 179 & 83 & & & \\
\hline & Resting, sustained arm or hand work & $0.1,0.5$ & 183 & 67 & \multirow{4}{*}{$21-23$} & \multirow{4}{*}{4.16} & \multirow{4}{*}{$48-77$} \\
\hline & Resting, sustained arm or hand work & $0.1,0.5$ & 179 & 83,101 & & & \\
\hline & Sustained arm or hand work & $0.1,0.5$ & 170 & 52 & & & \\
\hline & Sustained arm or hand work & $0.1,0.5$ & 170 & 68 & & & \\
\hline & Resting, sustained arm or hand work & 0.1 & 170 & 68 & \multirow{5}{*}{$22-23$} & \multirow{5}{*}{4.17} & \multirow{5}{*}{$46-82$} \\
\hline & Sustained arm or hand work & 0.1 & 183 & 67 & & & \\
\hline & Sustained arm or hand work & $0.1,0.5$ & 179 & 83 & & & \\
\hline & Resting, sustained arm or hand work & $0.1,0.5$ & 170 & 52 & & & \\
\hline & Resting, sustained arm or hand work & 0.5 & 179 & 101 & & & \\
\hline & Resting, sustained arm or hand work & $0.1,0.5$ & 183 & 67 & \multirow{5}{*}{$24-25$} & & \\
\hline & Resting, sustained arm or hand work & $0.1,0.5$ & 179 & 101 & & & \\
\hline & Sustained arm or hand work & $0.1,0.5$ & 170 & 52 & & 3.88 & $35-85$ \\
\hline & Sustained arm or hand work & 0.1 & 170 & 68 & & & \\
\hline & Sustained arm or hand work & $0.1,0.5$ & 179 & 83 & & & \\
\hline & Resting & 0.1 & 170 & 52,68 & & & \\
\hline & Resting, sustained arm or hand work & $0.1,0.5$ & 179 & 83 & $20-22$ & 3.33 & $46-75$ \\
\hline & Resting & 0.5 & 183 & 67 & & & \\
\hline & Resting & 0.1 & 170 & 52,68 & & & \\
\hline Very hot & Resting & 0.1 & 179 & 83 & $21-23$ & 4.16 & $48-77$ \\
\hline$\left(>41^{\circ} \mathrm{C}\right)$ & Resting & $0.1,0.5$ & 183 & 67 & & & \\
\hline & Resting & $0.1,0.5$ & 170 & 52,68 & & & \\
\hline & Resting & $0.1,0.5$ & 179 & 83 & & & \\
\hline & Resting & 0.5 & 179 & 101 & $24-25$ & 3.88 & 35-85 \\
\hline & Resting & 0.5 & 183 & 67 & & & \\
\hline
\end{tabular}

\section{Analyzing the Results of PET Evaluation}

The aims of the final section consist of analyzing results of the CFD simulation to reach a better understanding of the thermal comfort condition of the campus, the causes and effects on comfort and non-comfort areas, and give suggestions to improve outdoor thermal comfort.

The first analysis of the results of PET relates to how the range of PET depends on the personal and weather data. Table 8 shows the ranges of PET in different samples with the range of activities (metabolic rate: $65 \mathrm{~W} / \mathrm{m}^{2}$ at rest and $165 \mathrm{~W} / \mathrm{m}^{2}$ at high activity), $\mathrm{I}_{\mathrm{cl}}(0.1$ and $0.5 \mathrm{clo})$ and microclimatic conditions on campus on $4,7,10$, and $11 \mathrm{June}$. For example, according to Table 8 , on a day with a dry bulb temperature of $22-23^{\circ} \mathrm{C}$, wind speed of $4.17 \mathrm{~m} / \mathrm{s}$ and relative humidity of $46-82 \%$, only people with a height of 170 and 
$179 \mathrm{~cm}$ and weight of 68 and $83 \mathrm{~kg}$, respectively, can experience a slightly warm thermal comfort feeling, while their clothing level is 0.5 and they are doing the least activity.

Thus, the results of Table 8 give enough data to understand the relation between thermal comfort value, human body surface, the activity level, $\mathrm{I}_{\mathrm{cl}}$, and weather data. For example, in the same weather condition a person of $170 \mathrm{~cm}$ height and $68 \mathrm{~kg}$ weight can experience different ranges of PET that represent a normal body area, depending on the level of activity and preferred clothing level

Figure 12 shows a simple example based on the microclimatic data of 10 June 2021. For example, if a person has only a baseline activity level $\left(65 \mathrm{~W} / \mathrm{m}^{2}\right)$ and wears the lowest clothing $(0.1)$, it is hot PET (i.e., $35-41^{\circ} \mathrm{C}$ ), while the person with more clothing $\left(\mathrm{I}_{\mathrm{cl}}=0.5\right)$ has a lower value of PET, i.e., slightly warm in the range of $23-29^{\circ} \mathrm{C}$. If the same person has a higher activity level (metabolic rate of $165 \mathrm{~W} / \mathrm{m}^{2}$ ) with the same microclimatic data, the thermal comfort is hot or warm, at $\mathrm{I}_{\mathrm{cl}} 0.1$ and 0.5 respectively.

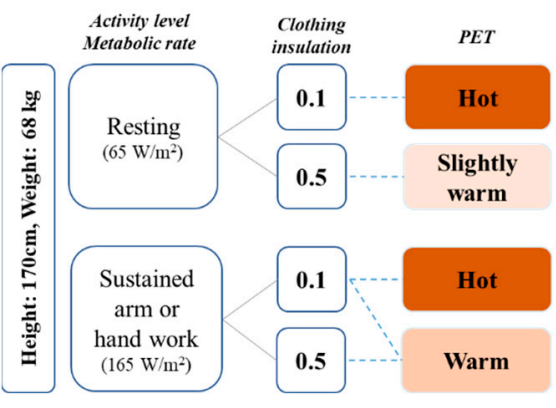

Figure 12. Different PET ranges, based on the microclimatic data on 10 June 2021.

\section{Application of the Study Results}

\subsection{Visualizing the Results}

The visual map calibrates the output data of the PET results to facilitate the application of thermal comfort while showing the diversity of the thermal environment.

Figure 13a,b shows how activity level affects the thermal comfort of PET for two identical individuals engaged in different activities. For the case p $3 \mathrm{~m} 2 \mathrm{c} 1$ with high metabolic rate and low clothing, thermal comfort in different parts of the campus ranges $24.5-55.5{ }^{\circ} \mathrm{C}$ (Figure 13a). According to thermal comfort evaluation, in this condition, most parts of the campus are comfort with slightly warm and warm thermal comfort values. However, in Figure $13 \mathrm{~b}$ evaluated thermal comfort value for the person (p4m1c2), with lower metabolic rate and higher level of clothing is in the higher ranges $27.70-54.10{ }^{\circ} \mathrm{C}$. Thus, most areas of the campus are considered non-comfort areas, meaning hot or very hot.

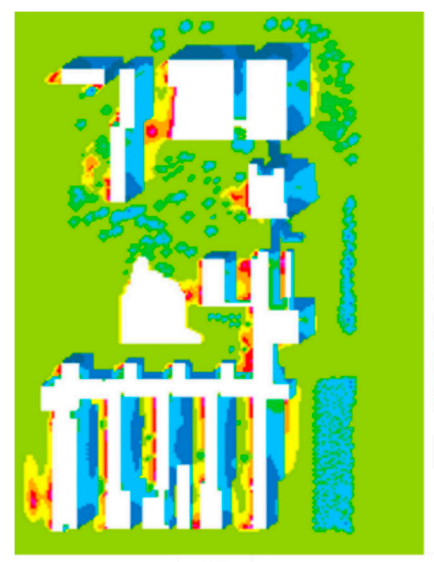

(a)

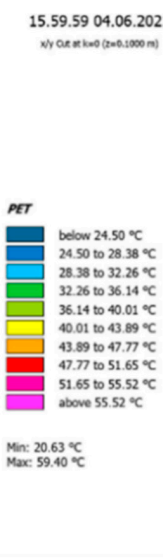

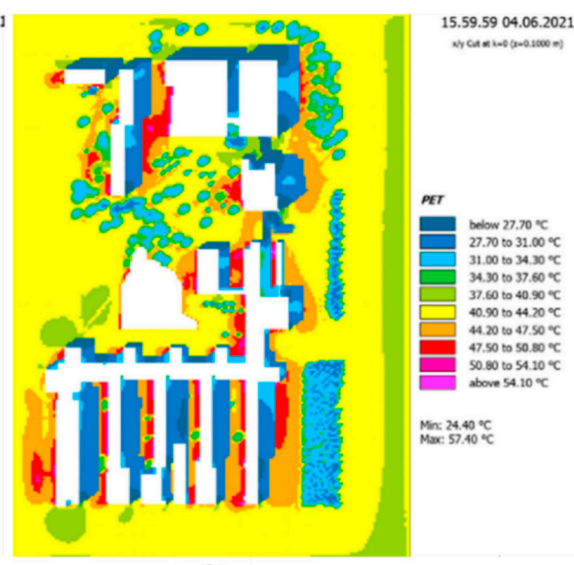

(b)

Figure 13. Visual results of PET of evaluation sample p3m2c1 on 4 June (high level of activity) (a), Visual results of PET of evaluation sample p4m1c2 on 4 June (low level of activity) (b). 


\subsection{Mitigation Strategies for the Improvement Thermal Comfort}

This paper aims to assess outdoor thermal comfort by focusing on bridging the disciplines by examining the relationships between objectively measured weather conditions and subjectively perceived thermal comfort, as well as the spatial characteristics of the area studied, as explained in Section 1.2. Therefore, matching the results is necessary to find the optimal areas for thermal comfort with the areas that need to be improved to meet people's needs. Similarly, we determine which features and characteristics cause this zone to be highlighted with high or low levels of thermal comfort perception according to PET ranges shown in Table 8. Firstly, we searched for areas in the high range of thermal comfort in each date (Figures 14 and 15). Secondly, we looked for the reason why some areas are thermally comfortable and others are not. In this step, the areas that have PET in the range of $35-41{ }^{\circ} \mathrm{C}$ and more than $41^{\circ} \mathrm{C}$ are classified as "hot" and "very hot", respectively. We consider "very hot" areas needed of thermal comfort improvements. The final part of this assessment is to find out which areas of the campus are more suitable for different activities.

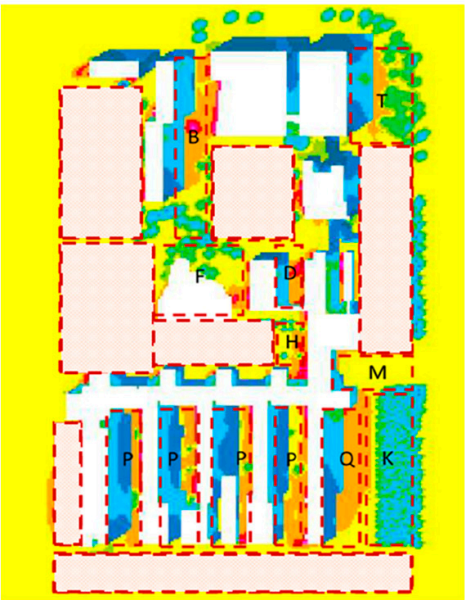

(a)

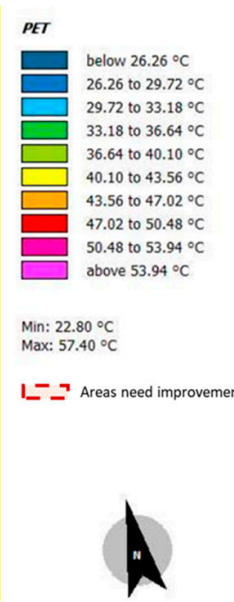

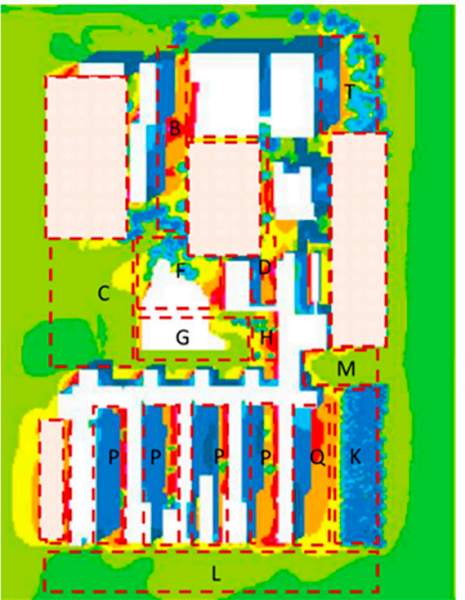

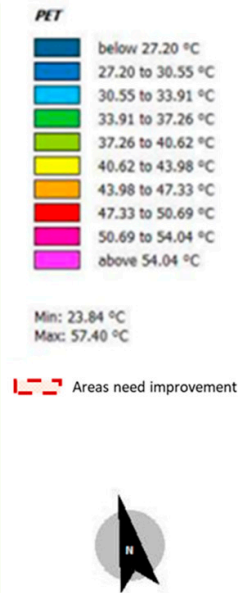

(b)

Figure 14. Visual results of PET and areas with PET values higher than need improvement, sample $\mathrm{p} 4 \mathrm{~m} 2 \mathrm{c} 1$, date 4 June, based on the microclimatic data of the campus (a), sample p1m1c1, date 7 June, based on the microclimatic data of the campus (b).

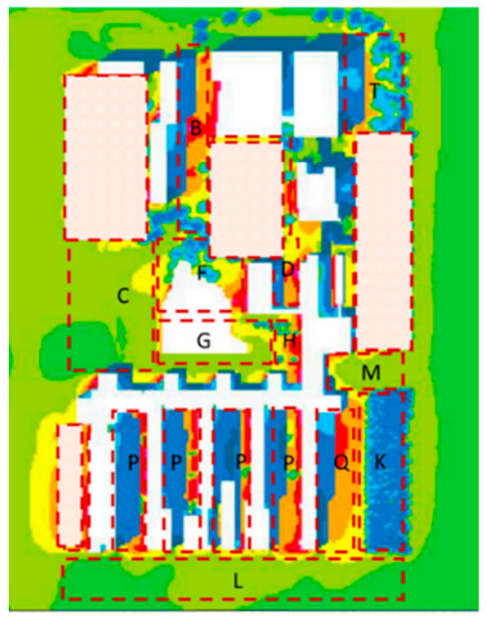

(a)
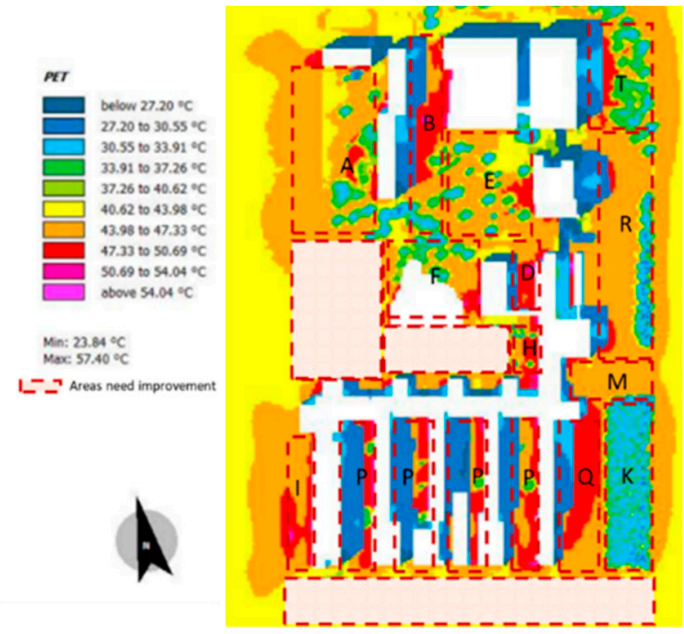

(b)

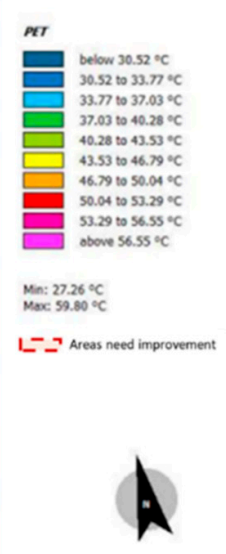

Figure 15. Visual results of PET and areas with PET values higher than need improvement sample $\mathrm{p} 2 \mathrm{~m} 1 \mathrm{c} 1$, date 10 June, based on the microclimatic data of the campus (a), sample p3m1c1, date 11 June, based on the microclimatic data of the campus (b). 
In summary, based on the analysis and according to Figure 16, outdoor areas: A, C, E, G, L, I, and R needs improvements to offer the better thermal comfort.
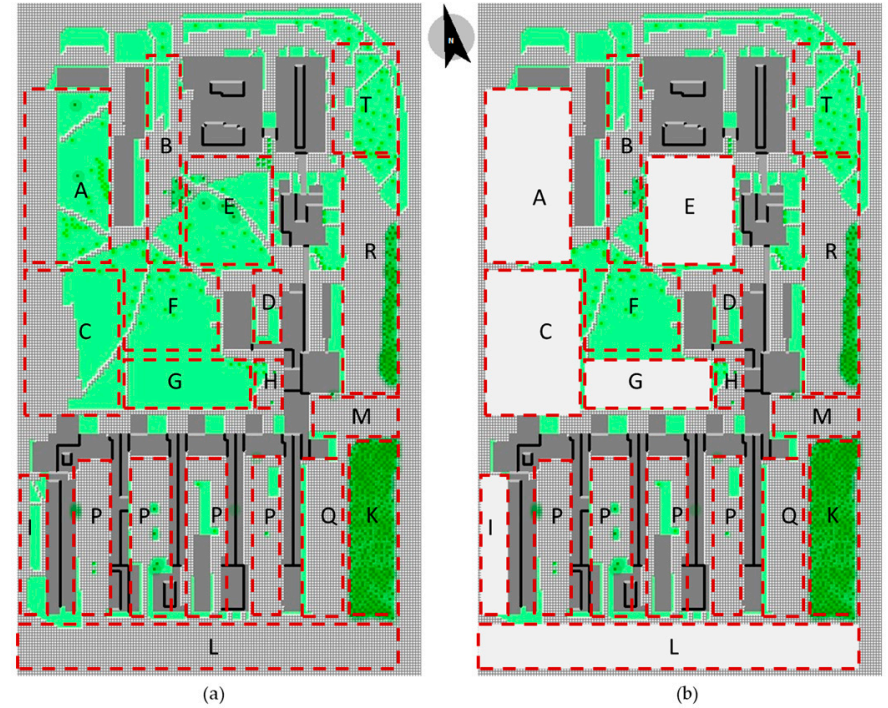

Figure 16. Different areas in the campus, generated in ENVI-met (a), areas needing improvement (b).

Table 9 uses the information areas in the campus in Figure 16 to define the major elements and the possible activities (the common activities based on the survey, Table 9). In this part of the study, we use the label of comfort or non-comfort to categorize areas in the campus based on PET assessment in the study.

Table 9. Specification of different part of the campus and the comfort level based on PET analysis.

\begin{tabular}{|c|c|c|c|c|}
\hline Name & The Major Elements & $\begin{array}{c}\text { Possible Activities (Based on PET } \\
\text { Evaluation) }\end{array}$ & Main Plants & Comfort Lable \\
\hline A & Green area & Chilling out, reading & Grass, trees & Non-comfort \\
\hline B & pavement & Hang out, walking, camping & Grass, bushes & Comfort \\
\hline $\mathrm{C}$ & Green area, pavement & Chilling out, reading & Grass, bushes & Non-comfort \\
\hline $\mathrm{D}$ & Green area, pavement & Hang out, walking, camping & Grass, pavement & Non-comfort \\
\hline $\mathrm{E}$ & Green area & Chilling out, reading & Grass, bushes, trees & Comfort \\
\hline $\mathrm{F}$ & Green area & Hang out, walking, camping & Grass, bushes, trees & Non-comfort \\
\hline G & Green area & Chilling out, reading & Grass & Comfort \\
\hline $\mathrm{H}$ & Green area, pavement & Hang out, walking, camping & Grass & Comfort \\
\hline I & Green area, pavement & Chilling out, reading & Grass & Non-comfort \\
\hline $\mathrm{K}$ & Green area & Hang out, walking, camping & Grass, trees & \\
\hline $\mathrm{L}$ & Pavement, street & Chilling out, reading & - & Non-comfort \\
\hline M & Pavement, parking lot & Hang out, walking, camping & - & Comfort \\
\hline Q & $\begin{array}{c}\text { Pavement, parking lot, } \\
\text { green area }\end{array}$ & Hang out, walking, camping & - & Comfort \\
\hline $\mathrm{P}$ & $\begin{array}{c}\text { Pavement, parking lot, } \\
\text { green area }\end{array}$ & Hang out, walking, camping & Grass, tress & Comfort \\
\hline
\end{tabular}

According to the survey data and the results of Table 9, Figure 17 shows different areas of the campus under the labels to define which areas are comfortable and popular, which are not comfortable but preferred by people, and likewise which areas are comfortable but not attractive to people based on the analysis, and finally which areas are neither comfortable nor attractive to people.

Figure 17 also shows that people prefer to spend their time and various activities such as computer work, dancing, picnicking, sunbathing, etc. in the main inner courtyard and mostly green areas of the campus such as A, C, E, and G. The area labeled L is also not 
pleasant but is popularly used as a bicycle path. Although park areas such as $\mathrm{P}, \mathrm{Q}, \mathrm{R}$, and $\mathrm{K}$ offer thermally pleasant conditions and benefit from the shade of surrounding buildings, they are not attractive to people. In addition, some interviewees consider these areas to be places with great potential for improvement. There are also some areas in the middle of the campus, (e.g., B, F, D, and H), which are both comfortable and used by people for various activities such as gathering, reading, and sunbathing. Finally, the area marked $\mathrm{T}$ in the northern part of the map provides optimal thermal comfort and is also a green space, but not very popular due to the high acoustic pollution related to the traffic flow

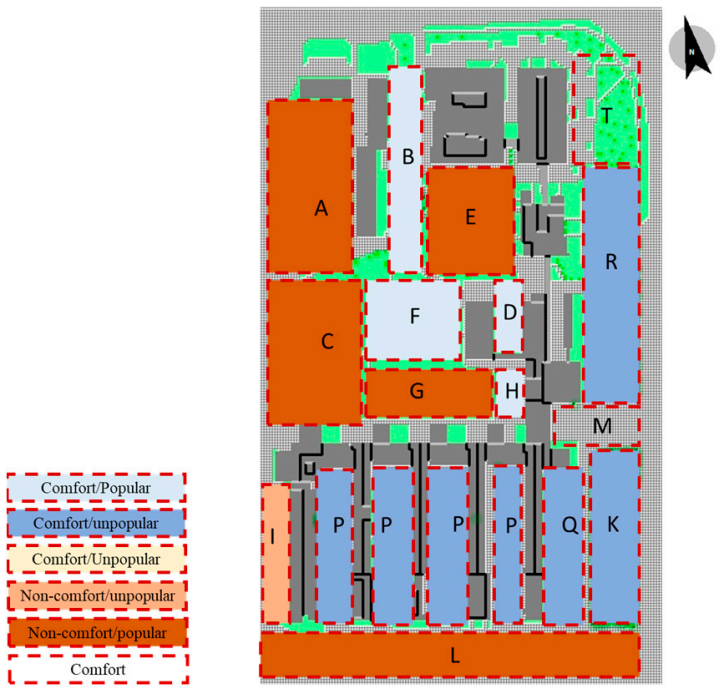

Figure 17. Comparison between the areas that are more popular for different activities and the comfort or non-comfort areas based on PET analysis.

\section{Conclusions}

The aim of the study is to use objective and subjective elements to assess outdoor thermal comfort at Tallinn University of Technology, Tallinn, Estonia, using qualitative and quantitative approaches. In this study, we mainly wanted to show how to use this mixed-methods approach to identify which areas of an urban area would be needed improvement of the outdoor thermal comfort during summer. The main outcomes and practical implications of this study are as follows:

1. The analysis of the relationship between personal characteristics and perception of thermal comfort shows that height, weight, degree of clothing, and activity level have an impact on thermal comfort values. The result shows that when the activity level is high, the level of clothing has no significant influence on the thermal comfort value. Furthermore, comparing people with high and low BMI under the same microclimatic conditions, with the same activity and clothing level, the maximum values of PET are higher in people with low BMI than in people with high BMI. Therefore, people with a lower BMI can move more under the same weather conditions without feeling uncomfortable compared to those with higher BMIs.

2. The analysis of non-environmental variables that depend on people has shown that the choice of place where people are active sometimes depends not only on pleasant thermal conditions, but also on other characteristics of the place, such as visual enjoyment, openness, or enclosure and green spaces. It is like some sun-exposed areas that are not pleasant according to the thermal comfort analysis, but which people choose for their activities. It is the same reason with areas between buildings or car parks that are shaded by the surrounding buildings and provide optimal thermal conditions, but are not chosen by people as places to stay because the lack of green/semi-open areas, and urban furniture. Based on the mentioned findings, it seems that spatial planning for site renovation and improvement should focus on the 
physical aspects of the areas, taking into account people's preferences to provide the enjoyable environment for visitors, while considering the thermal comfort of outdoor residents, e.g., by providing some shaded places. This concept covers part of Taltech's strategic plan in the project called Green Transition.

The sample size is a limitation of our study. Furthermore, we could not generalize our findings to all Taltech Campus users. Moreover, in this study assessment of thermal comfort is based on the PET metrics, but it can be done and evaluated in other indices such as the UTCI among others. The other limitation is related to the limited area and duration that thermal comfort assessed. Our assessment criterion of thermal properties of clothing might be conservative because we did not consider the wind effect on static clothing insulation. Thus, in summer conditions, the thermal comfort levels could be underestimated. Nevertheless, this approach could lead into design strategies which are on the safe side in future microclimate conditions, which can be further studied in future investigations.

Other future studies to complete this research and cover the limitations are planned in two parts. the study in the field of urban thermal comfort analysis in the campus will first explore possible solutions and strategies based on people's preferences and the results of the present study to improve the quality of thermal comfort on campus. Secondly, applying the solutions and reflecting them in the software environment of the urban simulator to analyses the CFD simulation of the campus to find the optimal one to improve areas with low thermal and non-thermal comfort. A future study will take into account a survey done with more participants in other zones of the city. The study will follow the results of thermal comfort assessment in different seasons in Tallinn through different comfort indices.

Author Contributions: Conceptualization, N.E., A.S. and F.D.L.; Applying qualitative method, A.S.; Applying quantitative method, modeling, simulation N.E.; Analysis, N.E. and A.S.; Methodology, N.E. and A.S.; Supervision, F.D.L. and K.S.L.; Results, N.E. and A.S.; Writing-original draft, N.E.; Writing-review and editing, N.E., A.S., F.D.L. and K.S.L. All authors have read and agreed to the published version of the manuscript.

Funding: This study was funded by the Smart City Centre of Excellence, Tallinn University of Technology.

Institutional Review Board Statement: The study was conducted in accordance with the Declaration of Helsinki, and approved by the Institutional Review Board (or Ethics Committee) of Tallinn University of Technology (Council Resolution No. 44 of 17 October 2017).

Informed Consent Statement: Informed consent was obtained from all subjects involved in the study.

Data Availability Statement: Not applicable.

Acknowledgments: This work has been supported by the European Commission through the H2020 project Finest Twins (grant No. 856602).

Conflicts of Interest: The authors declare no conflict of interest.

\section{Nomenclature}

CFD Computational Fluid Dynamics

PET Physiological Effective Temperature

PMV Predicted Mean Vote Index

PPD Predicted Percentage Dissatisfied Index

ISO International Organization for Standardization

MEMI Munich Energy-Balance Model for Individuals

UTCI Universal Thermal Climate Index

TSV Thermal Sensation Votes

BMI Body Mass Index

ASHRAE American Society of Heating, Refrigerating and Air-Conditioning Engineers

OUT_SET Outdoor Standard Effective Temperature 


\section{Appendix A}

The structure of the online survey

1. How old are you?

2. Which is your gender?

[Female, Male, Transgender female, Transgender female, Gender variant/non-coforming, Not listed, Prefer not to answer]

3. Which is your level of education?

4. Which is your current occupation?

5. Which months do you consider as part of the summer in Estonia?

[June, July, August]

6. How many summer periods have you been in Estonia?

7. How much is your height?

8. How much is your weight?

9. Do you have any physical disability? In affirmative case, which one?

10. Do you have any chronic disease? In affirmative case, which one?

11. Which outdoor activities do you usually practice during summer in Estonia?

Swimming at lakes, Swimming at the sea, Go surfing, Go paddle, Go surfing, Go kitesurfing, Tennis, Table tennis, Hang-out, Read a book, Dancing, Cricket, Baseball, Go picnic, Go Camping, Running, Jogging, Walking, Hiking, Football, Basketball, Beach-volleyball, Combat sports, Badminton, Street workout, Skateboarding, Longboarding, (e-)scooter, Chilling out, Other(s)

12. Please select the level of these variables to create a perfect summer day in Estonia to practice any of your preferred outdoor activities mentioned in question 11 (UVi $=\mathrm{UV}$ index):

\begin{tabular}{|c|c|c|c|c|c|}
\hline Solar radiation & Low (UVi = 1-2) & $\begin{array}{l}\text { Medium } \\
(\mathrm{UVi}=3-5)\end{array}$ & $\begin{array}{l}\text { High } \\
(\mathrm{UVi}=6-7)\end{array}$ & $\begin{array}{l}\text { Very high } \\
(\mathrm{UVi}>7)\end{array}$ & I do not mind \\
\hline Temperature (T) & $\begin{array}{l}\text { Low } \\
\mathrm{T}<20^{\circ} \mathrm{C}\end{array}$ & $\begin{array}{l}\text { Medium } \\
\mathrm{T}=20-25.9{ }^{\circ} \mathrm{C}\end{array}$ & $\begin{array}{l}\text { High } \\
\mathrm{T}=26-30{ }^{\circ} \mathrm{C}\end{array}$ & $\begin{array}{l}\text { Very high } \\
\mathrm{T}>30^{\circ} \mathrm{C}\end{array}$ & I do not mind \\
\hline Relative humidity (RH) & $\begin{array}{l}\text { Low } \\
(\mathrm{RH}<40 \%)\end{array}$ & $\begin{array}{l}\text { Medium } \\
(\mathrm{RH}=40-59.9 \%)\end{array}$ & $\begin{array}{l}\text { High } \\
(\mathrm{RH}=60-80 \%)\end{array}$ & $\begin{array}{l}\text { Very high } \\
(\mathrm{RH}>80 \%)\end{array}$ & I do not mind \\
\hline Precipitation & No rain & Light rain & Moderate rain & Heavy rain & I do not mind \\
\hline Wind speed & No wind & $\begin{array}{l}\text { Gentle breeze } \\
(<4 \mathrm{~m} / \mathrm{s})\end{array}$ & $\begin{array}{l}\text { Moderate wind } \\
(4-5 \mathrm{~m} / \mathrm{s})\end{array}$ & $\begin{array}{l}\text { Strong wind } \\
(>5 \mathrm{~m} / \mathrm{s})\end{array}$ & I do not mind \\
\hline Type of sky & Full overcast & Intermediate sky & Partially clear & Full clear sky & I do not mind \\
\hline
\end{tabular}

13. In which months do you use the outdoor areas of the Taltech Campus?

[June, July, August]

14. How far (in $\mathrm{km}$ ) do you live from Taltech Campus?

15. In which areas of the Taltech campus do you often spend time? (Figure 7)

16. According to your opinion, which spot(s) of the TalTech Campus are the less attractive to spend time in? (Figure 7)

17. How many hours per week do you enjoy the outdoor areas of the Campus during summer?

18. Which outdoor activities do you practice within the Taltech Campus during summer in Estonia?

Swimming at lakes, Swimming at the sea, Go surfing, Go paddle surfing, Go kitesurfing, Tennis, Table tennis, Hang-out, Read a book, Dancing, Cricket, Baseball, Go picnic, Go Camping, Running, Jogging, Walking, Hiking, Football, Basketball, Beachvolleyball, Combat sports, Badminton, Street workout, Skateboarding, Longboarding, (e-)scooter, Chilling out, Other(s) 
19. Please, select the main limitations of the actual outdoor areas of the Taltech Campus: Green areas, Lack of tables and chairs, Places with privacy, Conditions of the ground, Conditions of the ground, Actual laces to sit are uncomfortable, Accessibility with different ways of transport, Lack of plugs/sockets, Dirty spots, Lack of enough shadow in certain spots, Lack of benches in certain spots, Other(s)

20. Please, leave in the following box any comment you would like to express:

\section{References}

1. Chen, L.; Ng, E.Y.Y. Outdoor thermal comfort and outdoor activities: A review of research in the past decade. Cities 2012, 29, 118-125. [CrossRef]

2. Eslamirad, N.; Mahdavinejad, M. Multi Objective Computing and Applying Expert System in Double Skin Façade system. In Proceedings of the e-Energy '18: The Ninth International Conference on Future Energy Systems, Karlsruhe, Germany, 12-15 June 2018; pp. 459-461. [CrossRef]

3. Lai, D.; Zhou, C.; Huang, J.; Jiang, Y.; Long, Z.; Chen, Q. Outdoor space quality: A field study in an urban residential community in central China. Energy Build. 2014, 68, 713-720. [CrossRef]

4. Gehl, J. Life between the Buildings: Using Public Space. Available online: http:/ /www.krost-concern.ru/upload/life-betweenbuildings-1chapter.pdf (accessed on 15 February 2022).

5. Lenzholzer, S.; Klemm, W.; Vasilikou, C. Qualitative methods to explore thermo-spatial perception in outdoor urban spaces. Urban Clim. 2018, 23, 231-249. [CrossRef]

6. Ahmed, K.S. Comfort in urban spaces: Defining the boundaries of outdoor thermal comfort for the tropical urban environments. Energy Build. 2003, 35, 103-110. [CrossRef]

7. Nikolopoulou, M.; Lykoudis, S. Thermal comfort in outdoor urban spaces: Analysis across different European countries. Build. Environ. 2006, 41, 1455-1470. [CrossRef]

8. Wang, Z.; Wang, J.; He, Y.; Liu, Y.; Lin, B.; Hong, T. Dimension analysis of subjective thermal comfort metrics based on ASHRAE Global Thermal Comfort Database using machine learning. J. Build. Eng. 2019, 29, 101120. [CrossRef]

9. Alur, R.; Deb, C. The significance of Physiological Equivalent Temperature (PET) in outdoor thermal comfort studies. Int. J. Eng. Sci. Technol. 2010, 2, 2825-2828.

10. Luo, Y.; He, J.; Ni, Y. Analysis of urban ventilation potential using rule-based modeling. Comput. Environ. Urban Syst. 2017, 66, 13-22. [CrossRef]

11. Eslamirad, N.; De Luca, F.; Lylykangas, K.S. The role of building morphology on pedestrian level comfort in Northern climate. J. Phys. Conf. Ser. 2021, 2042, 012053. [CrossRef]

12. Li, K.; Zhang, Y.; Zhao, L. Outdoor thermal comfort and activities in the urban residential community in a humid subtropical area of China. Energy Build. 2016, 133, 498-511. [CrossRef]

13. Taleghani, M.; Kleerekoper, L.; Tenpierik, M.; van den Dobbelsteen, A. Outdoor thermal comfort within five different urban forms in the Netherlands. Build. Environ. 2015, 83, 65-78. [CrossRef]

14. Lai, D.; Guo, D.; Hou, Y.; Lin, C.; Chen, Q. Studies of outdoor thermal comfort in northern China. Build. Environ. 2014, 77, 110-118. [CrossRef]

15. Shaw, E. Thermal Comfort: Analysis and applications in environmental engineering, by P. O. Fanger. 244 pp. DANISH TECHNICAL PRESS. Copenhagen, Denmark, 1970. Danish Kr. 76, 50. R. Soc. Health J. 1972, 92, 164. [CrossRef]

16. d'Ambrosio Alfano, F.R.; Olesen, B.W.; Palella, B.I.; Povl, O.F. Impact Ten Years Later. Energy Build. 2017, 152, 243-249. [CrossRef]

17. Taleghani, M.; Tenpierik, M.; Kurvers, S.; van den Dobbelsteen, A. A review into thermal comfort in buildings. Renew. Sustain. Energy Rev. 2013, 26, 201-215. [CrossRef]

18. ASHRAE Standard. Thermal Environmental Conditions for Human Occupancy; ANSI/ASHRAE Standard 55-2004 (Supersedes ANSI/ASHRAE Standard 55-1992); American Society of Heating, Refrigerating and Air-Conditioning Engineers, Inc.: Atlanta, GA, USA, 1791. Available online: http:/ / www.ashrae.org (accessed on 15 February 2022).

19. Havenith, G.; Holmér, I.; Parsons, K. Personal factors in thermal comfort assessment: Clothing properties and metabolic heat production. Energy Build. 2002, 34, 581-591. [CrossRef]

20. Lin, T.-P. Thermal perception, adaptation and attendance in a public square in hot and humid regions. Build. Environ. 2009, 44, 2017-2026. [CrossRef]

21. Ng, E.Y.Y.; Cheng, V. Urban human thermal comfort in hot and humid Hong Kong. Energy Build. 2012, 55, 51-65. [CrossRef]

22. Kántor, N.; Égerházi, L.A.; Unger, J. Subjective estimation of thermal environment in recreational urban spaces-Part 1: Investigations in Szeged, Hungary. Int. J. Biometeorol. 2012, 56, 1075-1088. [CrossRef]

23. Krüger, E.; Drach, P.; Emmanuel, R.; Corbella, O. Assessment of daytime outdoor comfort levels in and outside the urban area of Glasgow, UK. Int. J. Biometeorol. 2012, 57, 521-533. [CrossRef]

24. Höppe, P. Different aspects of assessing indoor and outdoor thermal comfort. Energy Build. 2002, 34, 661-665. [CrossRef]

25. Fiala, D.; Havenith, G.; Bröde, P.; Kampmann, B.; Jendritzky, G. UTCI-Fiala multi-node model of human heat transfer and temperature regulation. Int. J. Biometeorol. 2011, 56, 429-441. [CrossRef] [PubMed] 
26. Nikolopoulou, M.; Baker, N.; Steemers, K. Thermal comfort in outdoor urban spaces: Understanding the human parameter. Sol. Energy 2001, 70, 227-235. [CrossRef]

27. Knez, I.; Thorsson, S.; Eliasson, I.; Lindberg, F. Psychological mechanisms in outdoor place and weather assessment: Towards a conceptual model. Int. J. Biometeorol. 2008, 53, 101-111. [CrossRef] [PubMed]

28. Böcker, L.; Dijst, M.; Faber, J. Weather, transport mode choices and emotional travel experiences. Transp. Res. Part A Policy Pract. 2016, 94, 360-373. [CrossRef]

29. Eliasson, I.; Knez, I.; Westerberg, U.; Thorsson, S.; Lindberg, F. Climate and behaviour in a Nordic city. Landsc. Urban Plan. 2007, 82, 72-84. [CrossRef]

30. Klemm, W.; Heusinkveld, B.G.; Lenzholzer, S.; van Hove, B. Street greenery and its physical and psychological impact on thermal comfort. Landsc. Urban Plan. 2015, 138, 87-98. [CrossRef]

31. Mahmoud, A. Analysis of the microclimatic and human comfort conditions in an urban park in hot and arid regions. Build. Environ. 2011, 46, 2641-2656. [CrossRef]

32. Zachariáš, J.; Stathopoulos, T.; Wu, H. Microclimate and Downtown Open Space Activity. Environ. Behav. 2001, 33, 296-315. [CrossRef]

33. Nikolopoulou, M.; Steemers, K. Thermal comfort and psychological adaptation as a guide for designing urban spaces. Energy Build. 2003, 35, 95-101. [CrossRef]

34. De Luca, F.; Naboni, E.; Lobaccaro, G. Tall buildings cluster form rationalization in a Nordic climate by factoring in indoor-outdoor comfort and energy. Energy Build. 2021, 238, 110831. [CrossRef]

35. Attaianese, E.; Alfano, F.R.D.; Palella, B.I.; Pepe, D.; Vanacore, R. An Integrated Methodology of Subjective Investigation for a Sustainable Indoor Built Environment. The Case Study of a University Campus in Italy. Atmosphere 2021, 12, 1272. [CrossRef]

36. Nazarian, N.; Sin, T.; Norford, L. Numerical modeling of outdoor thermal comfort in 3D. Urban Clim. 2018, 26, 212-230. [CrossRef]

37. Wania, A.; Bruse, M.; Blond, N.; Weber, C. Analysing the influence of different street vegetation on traffic-induced particle dispersion using microscale simulations. J. Environ. Manag. 2012, 94, 91-101. [CrossRef] [PubMed]

38. Peel, M.C.; Finlayson, B.L.; McMahon, T.A. Updated world map of the Köppen-Geiger climate classification. Hydrol. Earth Syst. Sci. 2007, 11, 1633-1644. [CrossRef]

39. De Luca, F. Outdoor Comfort Analysis in a University Campus during the Warm Season and Parametric Design of Mitigation Strategies for Resilient Urban Environments. Computer-Aided Architectural Design, "Design Imperatives: The Future is Now". In Proceedings of the 19th International Conference CAAD Futures 2021, University of Southern California, Los Angeles, CA, USA, 16-18 July 2021.

40. Available online: https://www.wunderground.com/history/monthly/ee/tallinn/EETN/date/2021-6 (accessed on 7 June 2021).

41. Taltech, Nzeb. Available online: https://taltech.ee/en/nzeb-technological-test-facility (accessed on 15 February 2022).

42. Chen, Y.-C.; Lin, T.-P.; Matzarakis, A. Comparison of mean radiant temperature from field experiment and modelling: A case study in Freiburg, Germany. Arch. Meteorol. Geophys. Bioclimatol. Ser. B 2014, 118, 535-551. [CrossRef]

43. Mills, J.; Birks, M. Qualitative Methodology: A Practical Guide; SAGE Publications, Inc.: Thousand Oaks, CA, USA, 2014; ISBN 9781446248980. [CrossRef]

44. Available online: https://www.wunderground.com/history/monthly/ee/tallinn/EETN/date/2021-6-7 (accessed on 15 February 2022).

45. Braun, V.; Clarke, V. Using thematic analysis in psychology. Qual. Res. Psychol. 2006, 3, 77-101, ISSN 1478-0887. [CrossRef]

46. Berkovic, S.; Yezioro, A.; Bitan, A. Study of thermal comfort in courtyards in a hot arid climate. Sol. Energy 2012, 86, 1173-1186. [CrossRef]

47. Gao, N.; Shao, W.; Rahaman, M.S.; Zhai, J.; David, K.; Salim, F.D. Transfer learning for thermal comfort prediction in multiple cities. Build. Environ. 2021, 195, 107725. [CrossRef]

48. Mehta, H.; Kanani, P.; Lande, P. Google Maps. Int. J. Comput. Appl. 2019, 178, 41-46. [CrossRef]

49. Blazejczyk, K. New climatological-and-physiological model of the human heat balance outdoor (MENEX) and its applications in bioclimatological studies in different scales. Zesz. IgiPZ PAN 1994, 28, 27-58.

50. Available online: https://www.engineeringtoolbox.com/clo-clothing-thermal-insulation-d_732.html (accessed on 16 November 2021)

51. Rawal, R.; Manu, S.; Shukla, Y.; Thomas, L.E.; de Dear, R. Clothing insulation as a behavioural adaptation for thermal comfort in Indian office buildings. In Proceedings of the 9th Windsor Conference: Making Comfort Relevant, Windsor, UK, 7-10 April 2016; pp. 403-415.

52. Alfano, F.R.D.; Palella, B.I.; Riccio, G.; Malchaire, J. On the Effect of Thermophysical Properties of Clothing on the Heat Strain Predicted by PHS Model. Ann. Occup. Hyg. 2015, 60, 231-251. [CrossRef] [PubMed] 